Aus dem Veterinärwissenschaftlichen Department der Tierärztlichen Fakultät

der Ludwig-Maximilians-Universität München

Arbeit angefertigt unter der Leitung von

Prof. Dr. Dr. M. Erhard

\title{
Untersuchungen zur postkolostralen Immunglobulin-G- Versorgung neugeborener Saugferkel mittels unterschiedlicher ELISA-Nachweissysteme
}

\author{
Inaugural-Dissertation zur Erlangung \\ der tiermedizinischen Doktorwürde \\ der Tierärztlichen Fakultät \\ der Ludwig-Maximilians-Universität München \\ von Astrid Pausenberger \\ aus Siegen
}

München 2012 
Gedruckt mit Genehmigung der Tierärztlichen Fakultät der Ludwig-Maximilians-Universität München

Dekan: $\quad$ Univ.-Prof. Dr. Braun

Berichterstatter: $\quad$ Univ.-Prof. Dr. Dr. Erhard

Korreferent/en: $\quad$ Univ.-Prof. Dr. Ritzmann

Tag der Promotion: 21. Juli 2012 
Für Emil 


\section{Gliederung}

1. Einleitung und Aufgabenstellung 3

2. Schrifttum 5

2.1. Kolostrum und Immunglobuline beim Schwein 5

2.1.1. Bedeutung 5

2.1.2. Immunglobuline beim Schwein 6

2.1.2.1. Klassen von Immunglobulinen 6

$\begin{array}{lll}\text { 2.1.2.2. } & \text { Grundstruktur }\end{array}$

2.1.2.3. Immunglobuline im Kolostrum 8

2.1.3. Aufnahme passiver Immunität durch das Ferkel 9

2.1.3.1. Kolostrumproduktion der Sau 9

2.1.3.2. Gebildete Menge an Kolostrum 10

2.1.3.3. Einflussfaktoren auf die Zusammensetzung des Kolostrums 13

2.1.3.4. IgG-Konzentration im Kolostrum 13

2.1.3.5. Verfügbarkeit von Kolostrum 14

2.1.3.6. Aufgenommene Menge an Kolostrum 15

2.1.3.7. Absorption von Immunglobulinen und Schluss der Darmschranke $\quad 17$

2.1.3.8. IgG-Konzentrationen im Blut von Ferkeln 19

2.1.3.9. Zusammenhänge zwischen Geburtsgewichten, Geburtsreihenfolge, Geschlecht, Zitzenposition und IgG-Konzentration im Ferkelblut 20

2.1.3.10. Eigensynthese von Immunglobulinen 22

2.2. Überprüfung der Kolostrumversorgung 24

2.2.1. Bedeutung 24

2.2.2. Nachweismethoden 25

2.2.2.1 Radiale Immunodiffusion 25

2.2.2.2. ELISA-Systeme 26

2.2.2.3. Mono- und polyklonale Antikörper 27

2.2.2.4. Der Colostrum Quality Counter 27 
3. Publizierte Studienergebnisse

A. Pausenberger, M. Erhard, K. Schuster: Untersuchungen zur postkolostralen Immunglobulin-G-Versorgung neugeborener Saugferkel mittels unterschiedlicher ELISA-Nachweissysteme.

Tierärztliche Praxis 2012; 40 (G) 77 - 84

4. Erweiterte Diskussion

4.1. Vergleich unterschiedlicher IgG-Konzentrationen in der Literatur

4.2. Zusammenhänge zwischen IgG-Konzentrationen und Alter, Geschlecht und Gewicht 39

4.3. Wurfweise Betrachtung

4.4. Abweichende Ergebnisse des CQC

4.5. Abweichungen von der CQC Anleitung

5. Zusammenfassung

6. Summary

Anhänge

Abkürzungsverzeichnis

Verzeichnis der Abbildungen, Tabellen und Anhänge 55

Gesamt-Literaturverzeichnis 56

Danksagung 65

Eidesstattliche Versicherung 66

Lebenslauf 67 


\section{Einleitung und Aufgabenstellung}

Prof. Paul Ehrlich schreibt 1892, ihn habe die Tatsache überrascht, „dass die Milch immunisierter Thiere den betreffenden Antikörper enthält und ihn mit Leichtigkeit in den Organismus der Säuglinge übertreten lässt““. Er hatte erste Versuche einer Mutterschutzvakzination bei Mäusen und Ziegen durchgeführt und kam zu der Erkenntnis, dass Muttermilch eine bedeutende Rolle beim Schutz Neugeborener vor Infektionskrankheiten spielt. Porter (1969) bestätigte die herausragende Bedeutung des Tranfers kolostraler Proteine von der Muttersau auf die Ferkel, da es offenbar kaum transplazentare Übertragung gebe. Bis heute hat sich an dieser Einschätzung nichts geändert und Wissenschaftler aus der ganzen Welt beschäftigen sich in zahllosen Arbeiten mit der maternalen Immunität.

Fragestellungen, ob, wie und inwieweit sich die Kolostrumaufnahme beeinflussen lässt, sind erst in den letzten Jahren wieder stärker in den Focus gerückt, da mit dem Aufkommen hochfruchtbarer Sauengenetiken die Anzahl lebendgeborener Ferkel pro Sau deutlich gestiegen ist (Farmer and Quesnel 2009). Die Anzahl lebendgeborener Ferkel allein führt aber noch nicht zu besseren Gewinnen für die Landwirte, vielmehr ist die Anzahl der abgesetzten Ferkel pro Sau und Jahr der relevante Leistungsparameter. Diese ergibt sich aus der Anzahl der lebend geborenen Ferkel abzüglich der Saugferkelverluste.

Als Zielvorgabe in der modernen Ferkelproduktion sind derzeit 30 abgesetzte Ferkel pro Sau und Jahr anzusehen; Grundlage dafür müssen zwangsläufig Würfe mit 16 und mehr lebendgeborenen Ferkeln sein. Je grösser aber ein Wurf, desto geringer werden die Geburtsgewichte und damit auch die Widerstandsfähigkeit der Neugeborenen (Straw 2006). Die Ernährung solcher Würfe kann mit Hilfe eines ausgeklügelten Managementsystems und des Einsatzes von Ammen sichergestellt werden, die zur Verfügung stehende Kolostrummenge ist aber begrenzt.

Laut Auswertungen des Zentralverband der deutschen Schweineproduktion (ZDS) lagen die Saugferkelverluste im Jahr 2010 bundesweit durchschnittlich zwischen 13,4\% und 16,8\% (ZDS 2011). In der modernen Schweineproduktion mit hohem Preisdruck findet sich hier ein naheliegender Ansatzpunkt zur unmittelbaren Verbesserung der Deckungsbeiträge. Den mit Abstand grössten Anteil an den Saugferkelverlusten haben die Ferkelfrühverluste, die in den ersten beiden Lebenstagen entstehen (Prange 2004). Die Neugeborenensterblichkeit ist direkt mit der 
Kolostrumaufnahme korreliert (Klobasa et al. 1981, Salmon et al. 2009). Ganz ohne Kolostrum wird ein Ferkel normalerweise nicht überleben. Aber auch eine zu geringe Aufnahme von Kolostrum hat nachteilige Effekte auf die Entwicklung frohwüchsiger und widerstandsfähiger Ferkel und beeinflusst letztlich auch die spätere Aufzucht- und Mastleistung (Nielsen et al. 2004). Bei überlebenden Ferkeln wurden signifikant höhere Gammaglobulinkonzentrationen gemessen als bei solchen, die vor dem 21. Lebenstag starben (Hendrix et al. 1978, DePassille et al. 1988, Klobasa et al. 1981).

Bei der Überprüfung der Kolostrumversorgung in einem schweinehaltenden Betrieb fehlte bisher eine anwender- und tierfreundliche Diagnostik. Die Messung des Immunglobulingehaltes im Ferkelblut setzt mit den verfügbaren Methoden einen venösen Zugang voraus. Der Arbeitsaufwand, die Kosten und nicht zuletzt auch der Stress für die besonders empfindlichen Neugeborenen ist erheblich, so dass solche diagnostischen Überprüfungen in der Praxis selten und wenn dann nur bei einer geringen Anzahl Ferkel durchgeführt werden. Eine Einzeltierdiagnostik ist aber als Grundlage einer fundierten Aussage ungeeignet. Der von der holländischen Firma FarmulaONE entwickelte Colostrum Quality Counter (CQC) würde auf den ersten Blick die Lösung bieten: das vom Tierschutzaspekt her umstrittene, aber noch zulässige Kupieren des Ferkelschwanzes wird genutzt, um einige Tropfen Blut zu gewinnen, die - auf ein spezielles Filterpapier aufgebracht - für eine quantitative IgG-Bestimmung ausreichen sollen. Der grosse Vorteil des neuen Tests - die einfache Probennahme - ist offensichtlich. Nun stellt sich die Frage, wie zuverlässig die Ergebnisse sind bzw. inwieweit sich vernünftige Korrelationen mit bewährten Serum-ELISAs herstellen lassen.

Ziel der vorliegenden Arbeit ist es, die Praxistauglichkeit des CQC zu erproben, die Resultate mit denen etablierter Tests $\mathrm{zu}$ vergleichen und mögliche Zusammenhänge zwischen Kolostrumversorgung, Geschlecht und Gewicht zu überprüfen. 


\section{Schrifttum}

2.1. Kolostrum und Immunglobuline beim Schwein

\subsubsection{Bedeutung}

Ein neugeborenes Schwein hat eine sehr begrenzte Fähigkeit, sich an seine Umwelt anzupassen. Die erste Kolostrumaufnahme unmittelbar nach der Geburt liefert zunächst Energie und Wärme (Prange 2004, Le Dividich et al. 1981, Ley et al. 2002), die das Ferkel hocheffektiv zu 91\% verwertet (Le Dividich et al. 1994). Darüberhinaus wird passive Immunität zum Schutz vor Infektionen post natum über das Kolostrum vermittelt (Rooke und Bland 2002, Farmer and Quesnel 2009). Die eptitheliochoriale Plazenta der Muttersau lässt keine Passage von Immunglobulinmolekülen zu, die Ferkel werden agammaglobulinämisch geboren (Sterzl et al. 1966, Brambell 1969, Bourne et al. 1978, Werhahn et al. 1981, Salmon et al. 2008). Aus dem Kolostrum werden zum Einen spezifische Antikörper vom Ferkel aufgenommen, daneben aber auch maternale Immunzellen sowie unterschiedliche immunmodulierende und antimikrobielle Substanzen wie Zytokine oder Lactoferrin sowie verschiedene Faktoren, deren Rolle für die Entwicklung des Immunsystems teilweise nicht vollständig geklärt sind (Butler et al. 2008, Wagstrom et al. 2000, Williams 1993). Kolostrum beeinflusst aber auch die Entwicklung der aktiven Immunität über die Menge an postnatal aufgenommenen maternalen Antikörpern (Klobasa et al. 1981). Bei der Übertragung zellulärer Immunität ist es von entscheidender Bedeutung, dass das aufgenommene Kolostrum von der eigenen Muttersau stammt. Tuboly et al. (1988) wiesen die Absorption kolostraler Lymphozyten nach. Ob und inwieweit diese Zellen auch tatsächlich eine Rolle bei der zellvermittelten Immunität des Ferkels spielen, ist noch nicht abschliessend geklärt (Straw 2006), allerdings gibt es Hinweise darauf, dass sie sehr wohl von Bedeutung sind: Bandrick et al. (2011) belegten die Übertragung und Aktivität Mycoplasma hyopneumoniae-spezifischer T-Zellen aus dem Kolostrum Mycoplasma hyopneumoniae-geimpfter Sauen. 


\subsubsection{Immunglobuline beim Schwein}

\subsubsection{Klassen von Immunglobulinen}

Immunglobuline sind Abwehrstoffe, die als Antigen-Antikörperreaktion auf bestimmte Reize hin durch Plasmazellen gebildet werden. Bei Schweinen sind vor allem IgG, M und A von Bedeutung, daneben wurde ein genetisch den Fleischfressern nahestehendes IgE nachgewiesen. Die Existenz von IgD beim Schwein ist umstritten.

Im Serum des Schweines ist IgG mit einem Anteil von etwa 80-85\% die vorherrschende Immunglobulinklasse, das zudem noch mit einer Halbwertszeit von 10 - 14 Tagen recht stabil ist (Curtis and Bourne 1970). Aus diesem Grund kann bei der Beurteilung der Kolostrumversorgung auf die Bestimmung von IgG zurückgegriffen werden, das dann stellvertretend für die Gesamtversorgung des Ferkels mit Immunglobulinen interpretiert wird. IgG wird in Milz, Lymphknoten und Knochenmark gebildet und spielt die Hauptrolle bei der spezifischen, humoralen Infektabwehr. Es liegt als Monomer vor und ist das kleinste Immunglobulin, daher ist es auch extravasal z.B. im entzündeten Gewebe anzutreffen. IgG-Antikörper bilden eine belastbare und über längere Zeit anhaltende spezifische Immunität (Tizard 2009).

Beim Schwein sind mittlerweile 11 IgG-Isotypen beschrieben, die sich teilweise nur sehr geringfügig unterscheiden und deren Bedeutung im Einzelnen noch nicht geklärt ist. Anders als beim Rind, wo sich die Subklassen G1 und G2 chromatograpisch trennen lassen ist eine eindeutige biochemische Unterscheidung der IgG-Isotypen des Schweines ist bisher nicht möglich, was weitergehende Untersuchungen erschwert (Butler et al. 2009).

IgM hat einen Anteil von etwa 12\% in Serum und Kolostrum. Wie IgG wird es vor allem in der Milz, den Lymphknoten und dem Knochenmark gebildet. Im Gegensatz zu IgG ist es deutlich grösser, es kann als Dimer oder sogar als Pentamer vorliegen und kommt folglich nur selten extravasal im Gewebe vor. IgM ist das wichtigste Immunglobulin im Rahmen der immunologischen Sofortreaktion. Es ist weniger spezifisch als IgG. Seine Konzentration steigt nach einer Infektion 
schnell an und fällt dann ab, wenn IgG ansteigt. Die durch IgM vermittelte Immunität ist kurzlebiger, die Halbwertszeit liegt bei 4 - 5 Tagen. IgM kommt auch als sekretorisches IgM vor, als solches spielt es vor allem im Darm eine Rolle (Tizard 2009).

IgA macht nur einen geringen Anteil der Serumimmunglobulinkonzentration aus, herrscht aber in Schleimhautsekreten vor. In der postkolostralen Milch stellt es den Hauptanteil der Immunglobuline. Es wird von Plasmazellen unter Schleimhautoberflächen gebildet, im Darm, den Bronchien, des Urogenitaltraktes, der Haut und der Milchdrüse. Seine Bedeutung liegt vor allem in der Infektabwehr auf Körperoberflächen, indem es die Anheftung von Pathogenen verhindert (Tizard 2009). Besonders bei der lokalen Immunität des Darmes ist es von herausragender Bedeutung (Straw 2006).

\subsubsection{Grundstruktur}

Immunglobulinmoleküle bestehen grundsätzlich aus zwei identischen Polypeptidketten, von denen jede eine schwere (H-) Kette und eine leichte (L-) Kette besitzt. Die beiden Ketten sind durch Disulfidbrücken zu einer Y-förmigen Struktur verbunden und können durch proteolytische Enzyme in verschiedene Fragmente zerlegt werden. Das Fc-Fragment befähigt den Antikörper an Abwehrzellen zu binden, die beiden Fab-Fragmente binden Antigene und übernehmen verschiedene Aktivitäten wie z.B. die Komplementaktivierung. Die Fab-Fragmente enthalten eine L-Kette und einen Teil der H-Kette sowie das N-Terminal des Immunglobulinmoleküls, das tierindividuell variabel ist und auch die Spezifität des Antikörpers bestimmt. Das Fc-Fragment besteht aus dem anderen Teil der H-Kette und enthält das spezieskonstante C-Terminal. In einem Individuum können Antikörper verschiedener Klassen mit identischen reaktiven Bezirken gegen dasselbe Antigen gebildet werden (Rolle und Mayr 2006). 


\subsubsection{Immunglobuline im Kolostrum}

Im Kolostrum kommen die Immunglobulinklassen $\mathrm{G}, \mathrm{M}$ und $\mathrm{A}$ in unterschiedlichen und zeitabhängig stark variierenden Konzentrationen vor. Im ersten Kolostrum ist IgG die vorherrschende Immunoglobulinklasse. Es repräsentiert unmittelbar nach Geburtsbeginn etwa 80\% der kolostralen Gesamtimmunoglobulinmenge (Bland et al. 1999). Von dieser Höchstkonzentration aus erfolgt ein rascher, exponentieller Abfall. 24 Stunden p. p. ist die IgG-Konzentration auf etwa 1/3 der Ausgangsmenge reduziert (Curtis and Bourne 1970, Frenyo et al. 1980/81, Milon et al. 1983, Klobasa et al. 1987). Eine Woche nach der Geburt stellt IgA mit etwa 50-60\% den Hauptanteil der Immunglobuline in der Milch. IgA spielt eine wichtige Rolle bei der enteralen Protektion und wird vom Ferkel nur in geringem Masse ins Blut aufgenommen (Straw 2006, Lay et al. 2002, Butler et al. 2009). Den niedrigsten Gehalt, der sich auch nicht entscheidend ändert, hat mit etwa 4\% IgM (Curtis and Bourne 1970). Im Gegensatz zu Rind und Mensch sind IgA und IgG im Kolostrum des Schweines um ein Vielfaches höher konzentriert als im Serum, die IgMKonzentrationen entsprechen sich in etwa (Bourne et al. 1978).

IgA konnte in Blutproben von Ferkeln vor Kolostrumaufnahme nicht nachgewiesen werden, dagegen fanden einige Autoren sehr niedrige IgG-Spiegel (Porter 1969, Frenyo et al. 1980/81) bzw. Spuren eines IgG-verwandten Proteins (Curtis and Bourne 1970) bereits in präkolostralem Ferkelserum. In anderen Studien konnte vor dem ersten Saugakt kein Gehalt an IgG nachgewiesen werden (Bland et al. 2003). Klobasa et al. (1981) fanden IgM bereits vor Kolostrumaufnahme. Auch im Blut neugeborener Kälber wurden IgG und IgM bereits präkolostral nachgewiesen (Bender et al. 2009). Einig sind sich aber sämtliche Autoren, dass der allergrösste Teil der Immunglobuline im Serum neugeborener Ferkel nach den ersten Saugakten aus dem Kolostrum stammt. Zwischen der Aufnahme von Kolostrum und dem Auftauchen von Immunglobulinen im Ferkelserum besteht eine enge zeitliche Korrelation (Bland et al. 2003).

Kolostrales IgG kommt ausschliesslich, IgM zum grössten Teil aus dem Blut der Sau, während IgA zum grössten Teil direkt in der Milchdrüse gebildet wird (Bourne et al. 1978, Straw 2006). Einige Tage vor der Geburt beginnt die Sau, IgG aus dem Blut in der Milchdrüse zu konzentrieren, gleichzeitig sinkt die IgG-Konzentration im Serum der Sau. Der Transfer wird über spezielle 
Rezeptoren im Epithel der Milchdrüse vermittelt (Bourne and Curtis 1973, Salmon et al. 2008). Bourne et al. (1978) folgerten daraus, dass Kolostrum als Serum-Transsudat zu bezeichnen ist, während die später verfügbare Sauenmilch mit über 90\% direkt in der Milchdrüse gebildetem IgM und IgA ein echtes Sekret darstellt.

2.1.3. Aufnahme passiver Immunität durch das Ferkel

Die Menge an Immunglobulinen, die einem Ferkel letztendlich zur Verfügung steht, unterliegt unterschiedlichen Einflüssen: von der Muttersau, vom Ferkel selbst und nicht zuletzt von seiner Umwelt im peripartalen Zeitraum. Die aufgenommene Menge an IgG wird bestimmt von der Menge an aufgenommenem Kolostrum, der Konzentration an IgG im Kolostrum und der absorbierten Menge an IgG durch das Ferkel (Bland et al. 2003). DePassille et al. (1988) schreiben den wichtigsten Einfluss auf die IgG-Aufnahme beim Ferkel der Muttersau zu. Die tatsächlich vom Ferkel absorbierte Menge an Immunglobulinen kann anhand der IgG-Konzentrationen im Blut dargestellt werden (Tizard 2009).

\subsubsection{Die Kolostrumproduktion der Sau}

Zu den Faktoren mit Einfluss auf die Kolostrumproduktion gehören Genotyp (Fahmy et al. 1972, Farmer et al. 2007, Farmer and Quesnel 2009), Wurfzahl (Le Dividich et al. 2004, Devillers et al. 2004, Farmer and Quesnel 2009), Alter und Körpergewicht bzw. Rückenspeckdicke (Farmer and Quesnel 2009). Über das Ausmass der Einflüsse sind die Autoren teilweise uneinig. Die Zusammenhänge zwischen Kolostrumproduktion und Geburtseinleitung bzw. Trächtigkeitsdauer sind nicht hinreichend geklärt und hier besteht zusätzlicher Forschungsbedarf (Devillers et al. 2007). 


\subsubsection{Gebildete Menge an Kolostrum}

Die Menge an Kolostrum, die eine einzelne Sau zu bilden imstande ist, ist begrenzt. Folglich sinkt mit zunehmender Wurfgrösse die aufgenommene Menge Kolostrum pro Ferkel und je grösser der Wurf, desto grösser ist auch die erforderliche Menge an Kolostrum. Limitierender Faktor der absolut zur Verfügung stehenden Menge an Kolostrum pro Ferkel ist zunächst die Muttersau (Farmer und Quesnel 2009). Die produzierte Gesamtmenge ist physiologischerweise grundsätzlich so ausgelegt, dass jedem Ferkel mehr Kolostrum zur Verfügung steht, als es zum Erreichen der notwendigen IgG-Versorgung benötigt (Frenyo et al.1980/81). Bei Würfen von mehr als 12 Ferkeln ist aber zu berücksichtigen, dass die absolut verfügbare Kolostrummenge für jedes zusätzlich geborene Ferkel sinkt (Devillers et al. 2007). Für jedes Ferkel muss eine Zitze verfügbar sein, durch Zitzenkonkurrenz können Situationen entstehen, in denen zu wenig Kolostrum zur Verfügung steht oder die Konzentration an IgG im Kolostrum zu niedrig ist (Bland et al. 2003).

Die pro Sau gebildete Gesamtmenge innerhalb der ersten 24 Stunden wird mit etwa 2 bis 5 kg angegeben (Devillers et al. 2007, Farmer and Quesnel 2009, Foisnet et al. 2010). Die Autoren sind sich aber einig, dass enorme individuelle Unterschiede bestehen. Foisnet et al. (2010) geben einen Mittelwert von 3,22 kg an und teilen die Sauen in Niedrigproduzierende zwischen 0,85 kg und 1,39 $\mathrm{kg}$ und Hochproduzierende zwischen 2,83 kg und 4,64 kg. Aus der Nachzucht der niedrigproduzierenden Sauen starben innerhalb der ersten 48 Stunden signifikant mehr Ferkel als aus der Vergleichsgruppe der hochproduzierenden Sauen.

Bei der Betrachtung der absolut gebildeten Gesamtmenge pro Sau ist anzumerken, dass sich deren Messung nicht ganz einfach gestaltet. Die aufgenommene Menge pro Ferkel wird anhand von Wiegungen vor und nach dem Saugakt geschätzt. Aufsummierte Wiegungsdifferenzen ergeben die Gesamtzunahme pro Wurf (Le Dividich et al. 2004). Unter Berücksichtigung von Korrekturfaktoren aufgrund von Harnproduktion und metabolischen Faktoren (Le Dividich et al. 1981, Bland et al. 2003, Foisnet et al. 2010) kann dann auf die gebildete Gesamtkolostrummenge pro Sau geschlossen werden (Devillers et al. 2007, Foisnet et al. 2010). Da es sich um Schätzungen handelt, ist immer mit einer mehr oder weniger grossen Ungenauigkeit zu rechnen. 
Die absolute Menge an produziertem Kolostrum wird beeinflusst von der Vitalität eines Wurfes, gemessen an der durchschnittlichen Zeitspanne zwischen Geburt und erstem Saugakt (Devillers et al. 2007). Die Wurfgrösse allein hat dagegen keinen Einfluss auf die Menge an gebildetem Kolostrum (Le Dividich et al. 2004, Devillers et al. 2004). Auch das Alter, die Geburtsdauer oder das Körpergewicht beeinflussen die Menge an gebildetem Kolostrum nicht unmittelbar (Devillers et al. 2004). Dagegen hat die Wurfzahl insofern einen Einfluss, als Jungsauen und Sauen in höheren Würfen eine tendenziell niedrigere Kolostrumproduktion haben als Sauen in den mittleren Würfen (Devillers et al. 2007, Klobasa et al. 2004). Daraus erklärt sich auch der Einfluss des Körpergewichts bzw. der Rückenspeckdicke der Sau, die niedriger wird, je länger sich die Sau in Produktion befindet.

Viele Faktoren können zu verminderter Milchleistung führen. Eine in diesem Zusammenhang in jedem Lehrbuch beschriebene Erkrankung ist der Mastitis-Metritis-Agalaktie-Komplex (MMA), eine fieberhafte Erkrankung der Sauen, die mit einem nahezu völligen Sistieren der Milchproduktion einhergeht. Sehr viel häufiger ist aber das peripartale Hypogalaktie-Syndrom der Sau (PHS), das mehr oder weniger subklinisch zu einer Unterversorgung der Ferkel mit Milch führt (Iben 2000) (siehe Abb 1). Das gleiche Phänomen wird von Reiner et al. (2009) als postpartales Dysgalaktiesyndrom der Sau beschrieben, zahlreiche andere Bezeichnungen werden verwendet.

Als Gründe werden viefältige physische und psychische Belastungsfaktoren angeführt, die letztendlich eine verminderte Milchleistung zur Folge haben. Äussere Stressoren aller Art führen über Hypothalamus und Hypophyse zu einer erhöhten Kortisolproduktion und einer verminderten Prolaktin- und Oxytocinausschüttung. Foisnet et al. (2010) schliessen für die von ihnen beschriebenen niedrigproduktiven Sauen aufgrund der fehlenden Temperaturerhöhung einen Zusammenhang mit dem MMA-Syndrom aus. Ob diese Sauen aber möglicherweise dem PHS zuzuordnen sind, bleibt offen. 
Abb. 3: Pathogenese des PHS (Iben 2000)

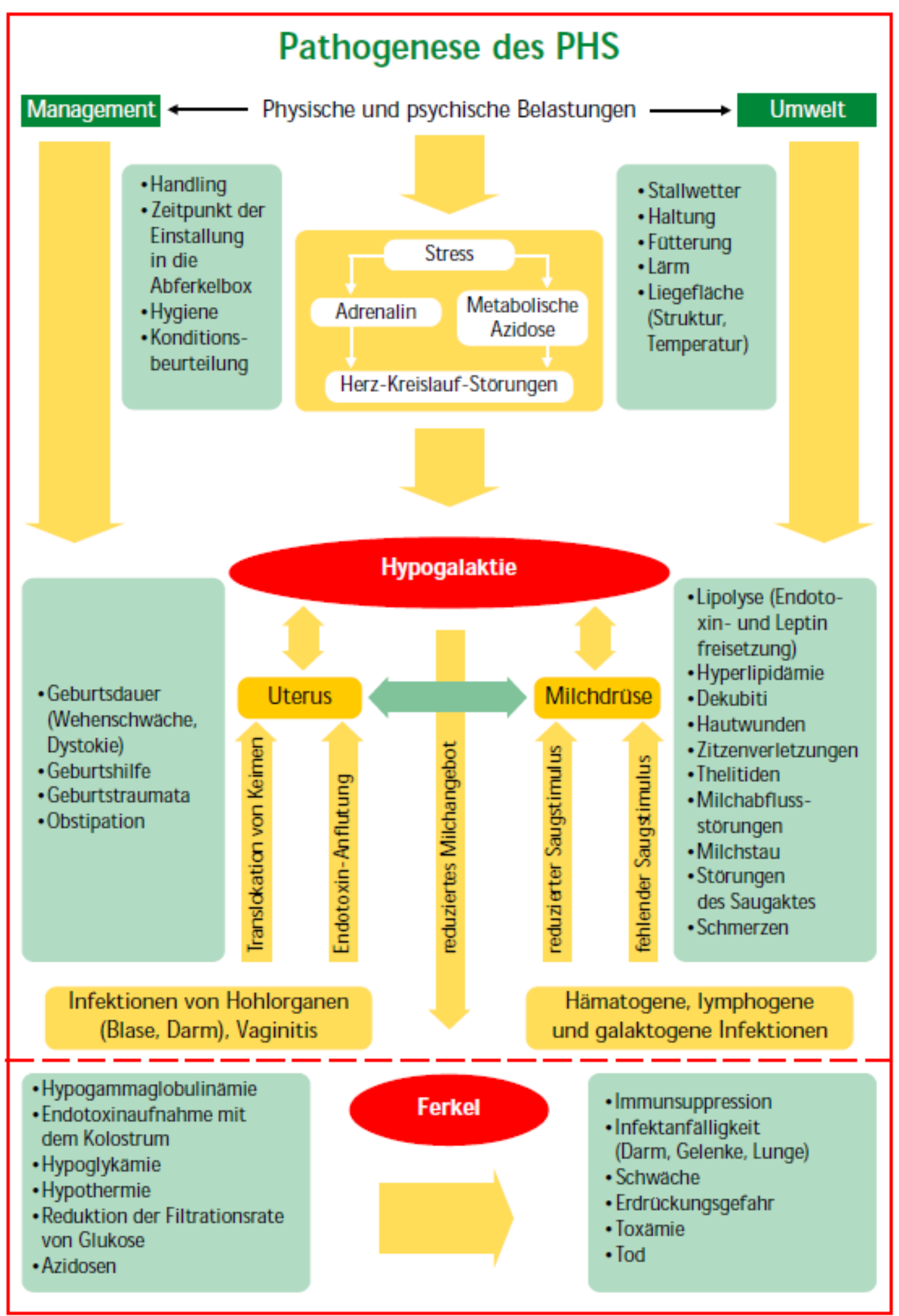




\subsubsection{Einflussfaktoren auf die Zusammensetzung des Kolostrums}

Unterschiedlichste Einflüsse auf die Kolostrumzusammensetzung sind bekannt. Das Verfahren der Muttertiervakzination zur Steigerung spezifischer Antikörperkonzentrationen im Kolostrum wird in der Rinder- und Schweineproduktion in grossem Umfang angewandt. Ob eine unspezifische Immunstimulation Einfluss auf die Immunglobulingehalte hat, ist umstritten. Krakowski et al. (2002) beschreiben eine Steigerung der IgG-Konzentration im Ferkelblut durch unspezifische Immunstimulation der Sauen. Kuhn et al. (2005) stellten einen signifikanten Anstieg der IgGKonzentrationen nach Echinacea-Fütterung fest; Lang (2004) konnte dagegen keinen Einfluss einer Echinacea-Fütterung an Sauen auf die IgG-Konzentrationen im Saugferkelblut feststellen.

Zuviel Futter in der Trächtigkeit beeinflusst die Bildung der Milchdrüsen negativ. Eine starke Reduktion von Fett in den letzten 14 Tagen der Trächtigkeit erhöht den Fettgehalt im Kolostrum, hat aber offenbar einen negativen Einfluss auf Proteingehalt und IgG-Konzentration (Göransson et al. 1990), ebenso wie eine Zufütterung von Fett, wobei die Art der zugefütterten Fette die Fettsäurezusammensetzung entscheidend beeinflusst (Farmer und Quesnel 2009). Der Zusatz von Vitamin A, C und E scheint den IgG-Status von Ferkeln zu verbessern; aber offenbar nicht über eine erhöhte Aufnahme, sondern eher über eine effektivere Absorption durch die Ferkel (Rooke and Bland 2002).

\subsubsection{IgG-Konzentration im Kolostrum}

In Hinblick auf die Übertragung humoraler Immunität von der Muttersau auf die Ferkel kann die Kolostrumqualität durch die Höhe der IgG-Konzentration definiert werden (Milon et al. 1983). Diese steht nicht in Zusammenhang mit der gebildeten Menge an Kolostrum (Foisnet et al. 2010). Die IgG-Konzentrationen im Kolostrum verschiedener Sauen weisen grosse individuelle Unterschiede auf (Klobasa und Butler 1987, Bland et al. 2003, LeDividich et al. 2004). Die Angaben zu den durchschnittlichen Maximalkonzentrationen schwanken zwischen 48,25 mg/ml 
(Frenyo et al. 1980/81), über $58 \mathrm{mg} / \mathrm{ml}$ (Bland et al. 1999) und 74,2 mg/ml (Foisnet et al. 2010) bis zu 85 mg/ml (Milon et al. 1983).

Die Konzentration an IgG im Kolostrum sinkt nach Geburtsbeginn sehr schnell ab (Klobasa et al. 1991, Devillers et al. 2007). Bereits nach den ersten Saugakten erfolgt ein dramatischer Abfall in der Ig-Konzentration des Kolostrums, vier bis sechs Stunden nach Geburtsbeginn um 50\% (Kruse 1983). 24 Stunden p.p. ist nur noch etwa 1/3 der Anfangskonzentration messbar (Curtis and Bourne 1970). Der Verlauf der IgG-Konzentration ist korreliert zur Anzahl der Saugakte und zur Gewichtszunahme des Wurfes innerhalb der ersten Lebensstunden (DePassille et al. 1988). Wenn kein Saugakt erfolgt, verzögert sich der Abfall der Gesamtproteinkonzentration in der Sauenmilch (Bourne 1969, Hendrix et al. 1978). Alter und Wurfzahl der Sauen haben ebenfalls einen Einfluss: Ältere Sauen haben tendenziell höhere Konzentrationen an Immunglobulinen im Kolostrum, wobei der Effekt bezüglich IgM und IgG erst nach dem 4. Wurf deutlich wurde (Klobasa und Butler 1987). Der Einfluss einer Geburtseinleitung scheint gering zu sein: Das Kolostrum der eingeleiteten Sauen unterschied sich hinsichtlich der IgG-Konzentration nicht von dem natürlich abgeferkelter Sauen (Milon et al. 1983). Devillers et al. (2007) stellten eine signifikante Minderproduktion bei eingeleiteten Sauen fest, schränkten das aber insofern ein, als Sauen erst ab dem 114. Trächtigkeitstag eingeleitet wurden und Trächtigkeitsdauer und Geburtseinleitung nicht klar getrennt voneinander betrachtet werden konnten.

Mehrfach untersucht wurde der Einfluss von Stress auf die IgG-Konzentrationen im Kolostrum bzw. im Blut der Ferkel. Pränataler Stress führt über die ACTH-Achse zu höheren Kortisolspiegeln im Blut der Sau und resultiert in signifikant niedrigeren IgG-Konzentrationen im Kolostrum und im Serum der Saugferkel (Machado -Neto et al. 1987, Tuchscherer et al. 2002).

\subsubsection{Verfügbarkeit von Kolostrum}

Neben der Menge und Qualität des Kolostrums spielt auch die Verfügbarkeit eine Rolle: In den ersten 3 Stunden nach Geburtsbeginn ist Kolostrum für alle Ferkel ständig verfügbar, gelegentlich kann auch schon vor Austreibungsbeginn ein Abtropfen von Kolostrum beobachtet werden. Eine zu frühe oder zu hoch dosierte Verabreichung von Depot-Oxytocin-Präparaten, wie sie für 
Geburtssynchronisationen durchgeführt wird, kann zu Verlust von Kolostrum durch Abtropfen führen (Prange 2004). Später - ab etwa 12 Stunden nach Geburtsbeginn - sind die Säugephasen synchronisiert (Fraser und Rushen 1992). Der Übergang zwischen kontinuierlicher und zyklischer Säugung erfolgt recht abrupt, und wird auf das Ausbleiben der Oxytocin-Ausschüttung während der Geburt zurückgeführt (Lewis und Hurnik 1985). Die Abstände zwischen den zyklischen Säugeperioden sind zunächst noch kürzer, später erfolgt etwa alle 40 - 60 min ein Milcheinschuss; der folgende Saugakt dauert dann etwa 1 Minute (Fraser and Rushen 1991).

\subsubsection{Aufgenommene Menge an Kolostrum}

Die individuell aufgenommene Menge an Kolostrum pro Ferkel kann absolut oder relativ zum Geburtsgewicht betrachtet werden. Der Einfluss des Geburtsgewichtes auf die aufgenommene Kolostrummenge kann bei relativer Betrachtung besser berücksichtigt werden. Absolut betrachtet führt ein um 100 g höheres Geburtsgewicht zu 18 g mehr aufgenommenem Kolostrum (Le Dividich et al. 2004).

Die Menge an Kolostrum, die ein normal saugendes Ferkel im Laufe des ersten Lebenstages aufnimmt, wird in der Literatur in einer Grössenordnung um $300 \mathrm{~g} / \mathrm{kg}$ angegeben (Le Dividich and Noblet 1981, Milon et al. 1983, Bland et al. 2003, Farmer and Quesnel 2008), eine realistische Empfehlung sind 280g/kg am ersten Lebenstag (Le Dividich et al. 1994). Bei ad libitum Flaschenfütterung wurden bis zu $450 \mathrm{~g} / \mathrm{kg}$ gemessen (Farmer und Quesnel 2008), den gleichen Wert findet man auch bei Devillers et al. (2007) als Maximalwert für normal saugende Ferkel. Um diese Werte angemessen beurteilen und vergleichen $\mathrm{zu}$ können, müssen die angewandten Schätzmethoden berücksichtigt werden (Devillers et al. 2004). Als Mindestmass zum Erreichen eines Gesamtproteingehaltes, der ein Überleben ermöglicht, geben Coalson and Lecce (1973) 40-60 g/Ferkel an. Svendsen et al. (2005) erreichen bei Ferkeln, die 4 mal je 30 ml Kolostrum/kg erhalten haben, Plasma-IgG-Spiegel, die mit denen natürlich aufgezogener Ferkel vergleichbar sind.

Die Wurfgrösse hat keinen unmittelbaren Einfluss auf die aufgenommene Kolostrummenge (Klobasa et al. 1987, De Passille et al. 1988, Devillers et al. 2004). Allerdings ist anzunehmen, dass in den älteren Arbeiten nur geringere Wurfgrössen betrachtet wurden. Bei Würfen über 12 Ferkel 
sinkt aber die verfügbare Kolostrummenge für jedes zusätzlich geborene Ferkel (Devillers et al. 2007).

Die aufgenommene Menge an Kolostrum hängt auch von anderen ferkelbezogenen Faktoren ab; zusammengefasst kann von Vitalität gesprochen werden. Indikator für die Vitalität ist die Zeit, die ein Ferkel von der Geburt bis zum ersten Saugakt benötigt (Foisnet et al. 2010). Sie umfasst die Fähigkeit, schnell aufzustehen, aktiv und erfolgreich nach dem Gesäuge zu suchen, sich gegen konkurrierende Wurfgeschwister durchzusetzen und eine grosse Kolostrummenge aufzunehmen (Edwards 2002). Die Vitalität ist eng vergesellschaftet mit neonataler Asphyxie (Herpin et al. 1996) und steht damit auch wieder in Zusammenhang mit dem Geburtsverlauf bzw. der Geburtsreihenfolge. Darüberhinaus besteht auch ein Zusammenhang der Vitalität zum Geburtsgewicht. Schwerere Ferkel können sich gegenüber leichteren besser durchsetzen und gewinnen mehr Kämpfe um Zitzen, sie erobern damit auch die besseren Zitzen (DePassille et al. 1988, Klobasa et al. 2004).

Spätgeborene Ferkel haben einen Nachteil gegenüber den Frühgeborenen. Eine Geburt dauert physiologischerweise um die $3-4$, Stunden, kann sich aber auch deutlich länger hinziehen. Von verzögerten Geburten wird ab etwa 8 Stunden gesprochen (Prange 2004). Ein um 8 oder 12 Stunden verspäteter Euterzugang reduziert die Menge an aufgenommenem Kolostrum (Bland et al. 2003). Die letztgeborenen Ferkel bekommen aber nicht nur eine geringere Menge an Kolostrum (Klobasa et al. 1981), sondern auch Kolostrum mit niedrigerer Immunglobulinkonzentration (Klobasa et al. 1981, Bland et al. 2003, Klobasa et al. 2004).

Vor dem physiologischen Geburtstermin eingeleitete Frühgeburten haben am ersten Tag eine geringere Kolostrumaufnahme als normalgeborene Ferkel (Milon et al. 1983). Auch Kältestress beeinträchtigt die Kolostrumaufnahme negativ (Le Dividich et al. 1981). 


\subsubsection{Absorption von Immunglobulinen und Schluss der Darmschranke}

Bei der Betrachtung der aufgenommenen Kolostrummenge muss berücksichtigt werden, dass sie nicht mit der Menge an aufgenommenen Immunglobulinen gleichzusetzen ist. Milon et al. (1983) nennen die Menge an aufgenommenem Kolostrum und dessen IgG-Konzentration als die wichtigsten Einflussfaktoren auf die IgG-Konzentration im Ferkelblut. Sie stellen aber fest, dass diese Faktoren einen nur unwesentlichen Einfluss auf die im Alter von 4, 12 oder 42 Tagen erhobenen Werte haben.

Die Aufnahme von Immunglobulinmolekülen aus dem Darm in das Blut ist auf die erste Zeit nach der Geburt beschränkt. Sie erfolgt durch Pinozytose (Straw 2006) und ist nicht isotypspezifisch (Bourne et al. 1978, Klobasa et al. 1981), wenngleich eine gewisse Selektivität hinsichtlich IgG zu beobachten ist (Rooke and Bland 2002). Von essentieller Bedeutung sind bei der Kolostrumaufnahme besonders die ersten Saugakte (Coalson and Lecce 1973, Prange 2004). Bei einer Halbwertszeit, die für die IgG-Konzentration im Kolostrum bei etwa 3 Stunden liegt, wird klar, dass die ersten Saugakte die grösste Bedeutung haben (Straw 2006). Etwa 60-70\% der Gesamtmenge an IgG werden innerhalb der ersten 12 Lebensstunden aufgenommen (Milon et al 1983, Fraser und Rushen 1992). Daraus folgt, dass die absolute Menge an aufgenommenen Immunglobulinen praktisch stündlich sinkt und der genaue Zeitpunkt, wann wirklich keine IgMoleküle aufgenommen werden können, von nachrangiger Bedeutung ist. Die Angaben zu diesem „Schluss der Darmschranke“ schwanken in der Literatur zwischen 12 und 48 h (Klobasa et al. 1991, De Passille et al. 1988, Nielsen et al. 2004, Rooke et al. 2003, Farmer et al. 2006, Straw 2006).

Welche Mechanismen genau zum Schluss der Darmschranke führen, ist nicht umfassend geklärt (Rooke et al. 2003). Der Zeitpunkt ist abhängig vom Alter des Ferkels und der Nahrungsaufnahme, wobei die ersten Saugakte und die Art der Nahrung eine grosse Rolle spielen (Broughton and Lecce 1970, Werhahn et al. 1981). Wenn ein Ferkel sofort nach der Geburt Kolostrum erhält, besteht 24 Stunden später keine Absorptionsfähigkeit für Immunglobulinmoleküle mehr. Wenn es hungern muss, ist eine Aufnahme von Immunglobulinen dagegen auch nach 24 Stunden noch möglich (Werhahn et al. 1981). Lecce und Morgan (1962) berichten von bis zu 86-stündiger Absorptionsfähigkeit von grossen Polyvinylpyrrolindon-Molekülen bei gefasteten Ferkeln. 
Ob es für den Schluss der Darmschranke von Bedeutung ist, dass das Futter Immunglobuline enthält, ist umstritten (Werhahn et al. 1981, Klobasa et al. 1981). Sicher scheint, dass die Aufnahme von Lactose den Schluss der Darmschranke fördert (Werhahn et al. 1981). Eine Aufnahme von 300 ml Milch, Kolostrum oder Zuckerlösung führte zum Ende der Ig-Absorption (Broughton und Lecce 1970).

Obwohl die Aufnahme von Immunglobulinen nicht isotypspezifisch verläuft (Bourne et al. 1978, Bland et al. 1999), scheint es doch Unterschiede in der Absorption von homologen und heterologen Immunglobulinen zu geben. Bei Ferkeln, die homologes Kolostrum aufgenommen haben, wurden Maximalwerte im Blutserum schneller erreicht als bei Ferkeln, die heterologes (Rinder-)Kolostrum aufgenommen hatten (Klobasa et al. 1991). Der Schluss der Darmschranke erfolgte bei Ferkeln, die heterologes Kolostrum oder Milchaustauscher erhielten, schneller als bei Ferkeln, die Schweinekolostrum bekamen (Jensen et al. 2001). Zumindest für Ratten ist ferner nachgewiesen, dass hohe Glucocorticoidspiegel die Permeabilität des Neugeborenendarmes für Antikörper negativ beeinflussen (Morris und Morris 1976). Ferkel von Sauen, die unter Hitzestress standen, hatten höhere Cortisolspiegel, die sie auch an ihre Ferkel weitergaben. Diese nahmen weniger IgG auf, das dann aber auch langsamer abgebaut wurde, sodass sich im Verlauf der ersten drei Lebenswochen die IgG-Konzentrationen an diejenigen der Kontrollferkel anglichen (Machado-Neto et al. 1987). Diese Beobachtungen decken sich mit denen von Milon et al. (1983), die feststellten, dass kleinere und schwächere Ferkel, die zunächst weniger Kolostrum aufnehmen, einen grösseren Anteil der aufgenommenen Immunglobuline speichern können.

Während Werhahn et al. (1981) eine direkte Proportionalität zwischen aufgenommener und absorbierter Menge an IgG feststellten, kommen andere Autoren zu unterschiedlichen Ergebnissen. Klobasa et al. (1991) weisen darauf hin, dass der Zeitpunkt des Erreichens der Maximalkonzentrationen von IgG im Blut grosse individuelle Unterschiede aufweist, und vermuten unterschiedliche Absorptionsfähigkeiten bereits kurz nach der Geburt. Svendsen et al. (1990) stellen fest, dass Spreizer und Ferkel mit einem niedrigen Geburtsgewicht von unter $1 \mathrm{~kg}$ ein grösseres Absorptionsvermögen für Makromoleküle haben als gesunde und schwerere Ferkel. Bland et al. (2003) bestätigen, dass zwischen Ferkeln offenbar individuelle Unterschiede in der Fähigkeit bestehen, Immunglobulinmoleküle aus dem Darm ins Blut zu überführen. Für das Rind kommen Bender et al. (2009) zu einem ähnlichen Schluss. 


\subsubsection{Ig-Konzentrationen im Blut von Ferkeln}

Erste IgG-Konzentrationen konnten im Plasma bereits 4 Stunden nach dem ersten Saugakt nachgewiesen werden (Bland et al. 2003). Maximale Serumkonzentrationen erreichen alle drei IgKlassen etwa 12 Stunden nach der Geburt (Klobasa et al. 1981), andere Autoren sehen das Maximum etwas später mit 24 Stunden (Yabicki et al. 1974, Frenyo et al. 1980/81,). IgG steigt dabei während der ersten 8 Stunden an und bleibt in den folgenden 16 Stunden konstant (Bland et al. 2003). Die Konzentrationen von IgG und A fallen dann bereits am 2. Lebenstag wieder sehr steil ab. Der weitere Abfall geschieht in etwa linear: bei IgM zwischen 12 h und 9 Tagen, bei IgA zwischen 2 und 18 Tagen und bei IgG zwischen 2 und 28 Tagen. (Curtis and Bourne 1971). Der schnelle Abfall am ersten Tag ist auf die Verteilung absorbierter Immunglobulinmoleküle zwischen extra- und intravasalem Raum zurückzuführen, später vor allem durch eine Verdünnung der Konzentrationen infolge Zunahme des Blutvolumens (Brambell 1969, Curtis and Bourne 1970, Frenyo et al. 1980/81). Die niedrigsten Konzentrationen werden in der Literatur grob übereinstimmend angegeben: für IgA etwa mit 3 Wochen, für IgM mit 2 Wochen und für IgG mit 4 bis 6 Wochen (Curtis und Bourne 1971, Frenyo et al. 1980/81, Klobasa et al. 1981). Diese Angaben zum Zeitpunkt maximaler und minimaler Immunglobulinkonzentrationen im Blut von Ferkeln sind Durchschnittswerte.

Wie bereits ausgeführt ist die Konzentration von IgG im Kolostrum einzelner Sauen ebenso unterschiedlich wie die durch ein Ferkel aufgenommene Menge an Kolostrum und die absorbierte Menge an IgG. Direkte Zusammenhänge zwischen der aufgenommenen Menge an IgG und den IgG-Konzentrationen im Blut bestehen bei natürlich saugenden Ferkeln nicht (Bland et al. 2003), ebensowenig wie zwischen den IgG-Konzentrationen im Kolostrum und den IgG-Konzentrationen im Blut (Frenyo et al. 1981/82, Klobasa et al. 1981). Die in den ersten drei Stunden post partum feststellbaren hohen Variabilitäten der IgG-Konzentrationen gleichen sich im Folgenden an (Frenyo et al. 1980/81). Unabhängig von den absorbierten IgG-Mengen unterscheiden sich die IgGKonzentrationen im Blut von Ferkeln innerhalb eines Wurfes ebenso wie zwischen verschiedenen Würfen später nur in geringem Masse, was den Schluss zulässt, das das Ferkel den Plasma-IgGSpiegel in gewissen Grenzen unabhängig vom aufgenommenen IgG regulieren kann (Bland et al. 1999). 
Ob die Verabreichungsdauer von Kolostrum einen Einfluss auf die IgG-Konzentrationen im Blut hat, ist umstritten. Werhahn et al. (1981) konnten keine Unterschiede in den Maximalwerten der Serum-IgG-Konzentrationen finden zwischen Ferkeln die 12 Stunden ununterbrochenen Kolostrumzugang hatten gegenüber Ferkeln, die nur wenige Stunden Zugang hatten. Nach Erreichen eines Höchstwertes steigen die IgG-Konzentrationen im Ferkelblut nicht mehr an, auch wenn noch viel mehr Kolostrum aufgenommen wird (De Passille et al. 1988, Farmer und Quesnel 2009). Während Klobasa et al. (1991) nach mehr als 12-stündiger Kolostrumfütterung keinen signifikanten Einfluss mehr nachweisen konnten, berichten Varley et al. (1987) von einer Erhöhung der IgG-Konzentrationen nach mehrtägig verlängerter Verabreichung von Kolostrum. Coalson and Lecce (1973) stellten fest, dass Ferkel, die nur 1 Stunde Zugang zu Kolostrum hatten, die überlebensnotwendige Menge an Immunglobulinen aufnehmen konnten.

Wenn kein Saugakt erfolgt, bleibt auch der steile Abfall der Gesamtproteinkonzentration in der Sauenmilch aus. Hendrix et al. (1978) stellten aber fest, dass die Konzentration an Immunglobulinen im Ferkelserum davon nicht beeinflusst wurde. Auch aus niedriger konzentriertem Kolostrum konnten die Ferkel ausreichend Immunglobuline resorbieren. Diese Erkenntnis konnten Bland et al. (1999) bestätigen: unterschiedliche IgG-Konzentrationen im Kolostrum resultierten nicht in signifikanten Unterschieden in der Plasma-IgG-Konzentration bei den Ferkeln.

\subsubsection{Zusammenhänge zwischen Geburtsgewicht, Geburtsreihenfolge, Geschlecht, Zitzenposition und IgG-Konzentration im Ferkelblut}

Die Einflüsse von Wurfgrösse, Geburtsgewichten, Geburtsreihenfolge, Geschlecht oder Zitzenposition auf die IgG-Konzentrationen im Ferkelblut werden von verschiedenen Autoren unterschiedlich beurteilt. Zusammenhänge zwischen Geburtsreihenfolge, Vitalität und Geburtsgewicht können bereits vor der Aufnahme von Immunglobulinen bestehen (Scheel et al. 1977). Dass eine hohe, negative Korrelation zwischen Geburtsgewichten und Überlebensrate besteht, ist unumstritten (Prange 2004). 
Zu möglichen Zusammenhängen zwischen Geburtsgewichten und IgG-Konzentrationen gibt es unterschiedliche Erkenntnisse. Varley et al. (1987), De Passille et al. (1988), Nielsen et al. (2004) und Galea et al. (2004) konnten keine Korrelationen ermitteln. Hendrix et al. (1978) fanden einen niedrigen, aber signifikanten Zusammenhang zwischen Geburtsgewicht und IgG-Konzentration, stellten aber fest, dass nur ein geringer Anteil der unterschiedlichen IgG-Konzentrationen auf die Geburtsgewichte zurückzuführen waren. Klobasa et al. (2004) finden grössere Unterschiede in den IgG-Konzentrationen besonders bei den leichtesten und schwersten Ferkeln im Vergleich zum Mittelfeld. Auch andere Autoren (Coalson and Lecce 1973, Scheel et al. 1977) führen das darauf zurück, dass sich stärkere Ferkel auch besser durchsetzen können. Männliche Ferkel haben tendenziell etwas höhere Geburtsgewichte, so dass sie auf diesem Weg einen leichten Vorteil vor weiblichen Wurfgeschwistern haben (Scheel et al. 1977); diese Beobachtung konnte von Nielsen et al. (2004) aber nicht bestätigt werden.

Interessant ist in diesem Zusammenhang die Betrachtung wurfweiser Durchschnittswerte. Es gibt keine Korrelation zwischen dem durchschnittlichen Geburtsgewicht oder der Wurfgrösse zur durchschnittlichen IgG-Konzentration. Würfe mit grösserer Variabilität der Geburtsgewichte hatten gegenüber homogeneren Würfen auch keine grössere Variabilität hinsichtlich der IgGKonzentrationen (DePassille et al. 1988).

Während Geburtsgewicht und Geburtsreihenfolge nicht zwangsläufig korreliert sind (Scheel et al. 1977), kommen später geborene Ferkel auch später ans Gesäuge und erhalten Kolostrum mit niedrigeren IgG-Konzentrationen. Im Vergleich zu Ihren Wurfgeschwistern haben die spätgeborenen Ferkel niedrigere Serum-IgG-Konzentrationen (Klobasa et al. 1981, Klobasa et al. 2004, Frenyo et al. 1981). Le Dividich et al. (2004) ermittelten hochsignifikante Unterschiede in den IgG-Konzentrationen von 48 Std alten Ferkeln: die Erstgeborenen lagen um 51\% über den Letztgeborenen. DePassille et al. (1988) erkennen einen Einfluss erst nach dem 8. Ferkel.

Im Verlauf der Säugephase bildet sich innerhalb eines Wurfes eine festgelegte Säugeordnung, jedes Ferkel hat „seine“ Zitze. Diese Ordnung entsteht erst innerhalb der ersten Tage. Die vorderen Zitzen haben eine höhere Attraktivität, über die Gründe dafür finden sich unterschiedliche Angaben: Die vorderen Zitzen produzieren mehr Kolostrum (Fraser et al. 1984), wodurch Ferkel an den hinteren Zitzen tendenziell etwas weniger Kolostrum aufnehmen können (Fraser und Rushen 1991) und Kolostrum aus den vorderen Zitzen enthält höhere IgG-Konzentrationen (Bland and Rooke 1998). 
Scheel et al. (1977) konnten eine signifikante Korrelation zwischen Zitzenposition und Geburtsgewicht feststellen. Stärkere i.e. schwerere Ferkel setzten sich bei Kämpfen um die besten Zitzen durch und waren entsprechend erfolgreicher.

Am ersten Lebenstag besaugt ein Ferkel noch verschiedene Zitzen. Die Anzahl besaugter Zitzen hat einen Einfluss auf die IgG-Konzentration im Blut: Wenn mehr als 5 verschiedene Zitzen besaugt wurden, war die IgG-Konzentration höher als wenn weniger Zitzen besaugt wurden (DePassille et al. 1988). Bland et al. (2003) beobachteten auch, dass Ferkel, die eine Zeitlang am Säugen gehindert wurden, mehrere Zitzen besaugen. Die Autoren nehmen an, dass dieses Verhalten entscheidend dazu beiträgt, den Rückstand gegenüber den Wurfgeschwistern erfolgreich aufholen zu können.

Die Überlebensfähigkeit eines Ferkels kann am umfassendsten durch die Beurteilung seiner Vitalität eingeschätzt werden (Foisnet et al. 2009). Bei vitaleren Ferkeln sind höhere IgGKonzentrationen zu erwarten. Schwerere Ferkel nehmen zwar grundsätzlich mehr Kolostrum auf, die aufgenommenen Immunglobuline verteilen sich aber in einem grösseren Volumen. Die grössere Menge schlägt sich folglich nicht unbedingt in einer höheren Ig-Konzentration im Blut nieder.

\subsubsection{Eigensynthese von Immunglobulinen}

Ein Anstieg der Konzentrationen von IgG im Blut beginnt nach natürlicher Aufnahme von Kolostrum etwa nach fünf Wochen post partum, von IgM nach etwa zwei Wochen und IgA nach etwa drei Wochen. Die Phase minimaler Immunglobulinkonzentrationen wird als „immunologische Lücke“ beschrieben (Lang 2004). Der Anstieg der Immunglobulinkonzentrationen ist jedoch nicht gleichzusetzen mit dem Beginn der Eigensynthese, die zunächst in sehr geringen Mengen erfolgt. IgG hat eine Halbwertszeit von etwa 10-14 Tagen, die Eigensynthese beginnt etwa vom 6.-10. Tag an (Klobasa et al. 1990, Butler et al. 2009, Rooke and Bland 2002). Für IgA werden Halbwertszeiten von 2-3 Tagen und für IgM von 3-4,5 Tagen angegeben (Butler et al. 2009). Erst mit etwa 10 Wochen sind die Ig-Konzentrationen adulter Tiere erreicht.

Bezüglich des Einflusses der Ig-Aufnahme auf die spätere Eigensynthese schreibt Wilson (1974), dass die eigene Antikörperproduktion unterdrückt wird, wenn das Ferkel homologe Antikörper über 
das Kolostrum erhalten hat. Klobasa et al. (1981) stellten fest, dass die im Alter von 56 Tagen gemessenen Immunglobulinkonzentrationen umgekehrt proportional zur aufgenommenen Menge an IgG war. Ferkel, die während des ersten Lebenstages kein oder nur wenig Immunglobuline aufgenommen haben, begannen früher mit der Eigensynthese. Die Unterdrückung der Eigensynthese von IgG und IgA durch die Aufnahme von Kolostrum konnte bei tiefgefrorenem Kolostrum aber nicht beobachtet werden. Allein durch die Aufnahme von IgG kann diese Unterdrückung folglich nicht zustande kommen (Klobasa et al. 1990). Zu einem anderen Schluss kamen Rooke und Bland (2002): Sie zeigten, dass die IgG-Eigensynthese des Ferkels positiv zur aufgenommenen IgG-Menge korreliert ist.

Zusammenfassend ist zu sagen, dass die Menge an Kolostrum und die Konzentration an IgG im Kolostrum innerhalb bestimmter Grenzen keinen signifikanten Einfluss auf die IgG-Konzentration im Ferkelblut haben. Ein individuell unterschiedliches Absorptions- oder Speicherungsvermögen kann Schwankungen bis zu einem gewissen Grad ausgleichen. Allerdings können bei sehr geringen Mengen oder sehr niedrigen Konzentrationen Mangelsituationen entstehen, die dann in einer echten Unterversorgung an Immunglobulinen resultieren (Rooke und Bland 2002). 


\section{2. $\quad$ Überprüfung der Kolostrumversorgung}

\subsubsection{Bedeutung}

Die Überprüfung der Kolostrumversorgung in einem schweineproduzierenden Betrieb kann dabei helfen, Mängel beim Sauen- oder Saugferkelmanagement zu identifizieren und letztendlich die Saugferkelverluste zu senken. Wenn Änderungen implementiert wurden, kann deren Effektivität überprüft werden. Wie unter 2.1. ausgeführt, sind die Einflussfaktoren auf Kolostrumproduktion und -aufnahme sehr vielfältig. Ob es sich um die Optimierung von Impfmassnahmen oder die Zusammenstellung von Futterrationen handelt, eine Überprüfung der kolostralen Versorgung kann in vielen Fällen sinnvoll sein. Die Messung des IgG Gehaltes im Ferkelblut hat gegenüber der weniger aufwändigen Messung direkt im Kolostrum den Vorteil, dass Klarheit darüber entsteht, wieviel IgG tatsächlich im Ferkel angekommen ist.

Maximalkonzentrationen von IgG im Ferkelblut werden im Verlauf des ersten Lebenstages gemessen, danach erfolgt ein Abfall. Bei einer beginnenden Eigensynthese ab der zweiten Lebenswoche und einer Plasmahalbwertszeit von etwa 10 bis 14 Tagen ist während der ersten 2 bis 7 Lebenstage nicht mit einer wesentlichen Änderung der Plasma-IgG-Werte zu rechnen. In diesem Altersbereich erhobene Werte repräsentieren demzufolge die Kolostrumaufnahme vor Schluss der Darmschranke (Rooke et al. 2003).

Kolostrale Immunglobuline allein sorgen aber noch nicht für eine niedrigere Saugferkelsterblichkeit. Varley et al. (1987) stellten fest, dass Ferkel, die bis zu 24 Stunden saugen durften, eine signifikant höhere Mortalitätsrate hatten als Ferkel mit 6-wöchiger Säugezeit. Auch wenn nach 24 Stunden kaum mehr kolostrales IgG aufgenommen werden konnte, waren die derart früh abgesetzten Ferkel weitaus empfänglicher für Infektionskrankheiten. Die IgG-Konzentrationen im Blut erlauben eine Einschätzung des generellen Immunstatus eines Tieres, aber keine Aussage zum Grad der Protektion vor bestimmten Pathogenen (Machado-Neto et al. 1987). 


\subsubsection{Nachweismethoden}

Porter (1969) beschreibt, wie er die IgG-, IgA- und IgM-Fraktionen aus der grossen Gruppe der Gammaglobuline isoliert, charakterisiert und quantifiziert. Die Immunoglobulin-Isolate wurden an Kaninchen verimpft, um Antiseren zu gewinnen. Als solche polyklonalen Antiseren zur Verfügung standen, wurde die „single radial immunodiffusion“ beschrieben, um Immunglobuline quantitativ zu erfassen (Butler et al. 2009). 1985 sind Varley et al. unter den Ersten, die einen Enzyme-linked immunosorbent Assay (ELISA) zum Immunglobulinnachweis einsetzen, seitdem werden unterschiedliche ELISA-Systeme genutzt. Sie sind heute wegen ihrer unkomplizierten Handhabung weit verbreitet und kommerziell verfügbar. Foisnet et al. (2010) nutzt mit dem Bethyl-ELISA den auch in der vorliegenden Arbeit eingesetzten Testkit, der in Deutschland über NatuTec vertrieben wurde und heute bei der Biomol Feinchemikalien GmbH in Hamburg erhältlich ist.

\subsubsection{Single Radial Immunodiffusion}

Bei dieser Methode handelt es sich um eine immunochemische Präzipitationsreaktion. Der isolierte Antikörper wird in einer definierten Konzentration in ein Agar-Gel eingegossen. Eine unbekannte Menge Antigen wird in eine Vertiefung gegeben von wo aus es in das Gel diffundiert und mit dem Antikörper reagiert. Da die Diffusion ringförmig um das Antigen herum erfolgt, wird sie als „radial“ bezeichnet und steht im Gegensatz zur linearen Ausbreitung, wo die Diffusion nur in eine Richtung erfolgen kann. Die vom entstandenen Ring umschlossene Fläche ist proportional zur Menge des Antigens in der Vertiefung. An einer zuvor mit bekannten Antigenkonzentrationen erstellten Standardgeraden/-kurve kann die Konzentration der unbekannten Antigenprobe abgelesen werden (nach Tizard 2009).

Die Methode der radialen Immunodiffusion wurde in vielen Studien verwendet (siehe auch Tab. 6) und ist nach wie vor in Gebrauch. Klobasa et al. (2004) erwähnen eine Wiederholbarkeit von >95\%. Für Ihre Untersuchungsmethode geben Fahey und McKelvey (1965) eine potentielle Abweichungsquote von +/- 10\% an. Bei niedrigen IgG-Konzentrationen lässt die Genauigkeit aber 
nach (Varley et al. 1985). In Europa wurde eher der Methode nach Mancini der Vorzug gegeben, in Amerika derjenigen nach Fahey and Mc Kelvey (Berne 1974). Der wesentliche Unterschied besteht in der Auswertung der erzielten Ergebnisse: Der Logarithmus der Antigen-Konzentration ist linear zum Durchmesser des Präzipitatringes (Fahey und McKelvey 1965), bzw. zur Fläche die vom Ring umschlossen wird (Mancini et al. 1965). Potentielle Fehlerquellen sind eine ungleichmässige Ausbreitung oder sehr niedrige Antigenkonzentrationen (Schumacher et al. 1968, Berne 1974, Varley et al. 1985). Für die Vergleichbarkeit und Reproduzierbarkeit der Ergebnisse ist es von entscheidender Bedeutung, dass die Präzipitatringe bzw. -flächen exakt zum selben Zeitpunkt ausgemessen werden, da sich die Reaktion mit fortschreitender Zeit weiter ausbreitet (Schumacher et al. 1968).

\subsubsection{ELISA-Systeme}

Enzyme-linked immunosorbent assays (ELISAs) sind $\mathrm{zu}$ den enzymatischen Immunadsorptionsverfahren zu zählen. Sie werden häufig eingesetzt um Proteine und Viren, aber auch Toxine oder Hormone nachzuweisen und evtl. auch zu quantifizieren. Beim direkten ELISA wird ein Antikörper in den Vertiefungen einer Mikrotiterplatte fixiert, der gegen das zu suchende Protein gerichtet ist. Das Protein bindet an diesen Antikörper und kann im zweiten Schritt mit einem weiteren enzymmarkierten Antikörper nachgewiesen werden. Die Markierung sorgt für einen Farbumschlag, dessen Intensität proportional zur Konzentration des gebundenen Antikörpers ist.

Beim indirekten ELISA ist ein bestimmtes Antigen auf einer Mikrotiterplatte fixiert. Bei Zugabe einer Testlösung, die den entsprechenden Antikörper enthält, bindet dieser Antikörper an das Antigen. Ungebundenes Antigen wird durch Waschen entfernt. Die gebundenen Antikörper werden durch Zugabe eines markierten enzymgebundenen Sekundärantikörpers (Konjugat) detektiert und es entsteht ein photometrisch messbarer Farbumschlag, der ebenfalls proportional zur Menge des Antikörpers ist.

Der Sandwich-Elisa ist eine Sonderform des indirekten ELISA, hier werden zwei Antikörper verwendet, das zu messende Antigen ist wie in einem Sandwich zwischen zwei Antikörpern gebunden. Eine Mikrotiterplatte wird mit einem spezifischen (capture-) Antikörper beschichtet, 
danach wird die Antigen-Lösung zugegeben. Nach dem ersten Waschen wird der DetektionsAntikörper (Konjugat) aufgebracht, der wiederum an das gebundene Antigen bindet. Das Substrat, das für den Farbumschlag sorgt, wird erst nach erneutem Waschen hinzugefügt. Beschichtung und Konjugat binden an unterschiedliche Epitope des Antigens (nach Tizard 2009, Rolle und Mayr 2006).

In den Anhängen 1 bis 3 sind die Protokolle der drei ELISAS MUC, NAT und CQC zu finden, die in der vorliegenden Arbeit verwendet wurden. Die wichtigsten Unterschiede sind in Tab. 1 in Kapitel 3 dargestellt.

\subsubsection{Mono- und polyklonale Anti-IgG-Antikörper}

Monoklonale Antikörper (mAbs) binden nur an ein bestimmtes Epitop eines Antigens und bieten folglich grundsätzlich eine höhere Spezifität. Sie bieten sich damit für die routinemässige Differenzierung der IgG-Subklassen an. Van Zaane und Hulst (1987) beschrieben die Produktion monoklonaler Antikörper gegen IgG und zwei Subtypen, obwohl den Autoren die Existenz weiterer Subtypen bekannt war. Franek (1987) arbeitete mit monoklonalen Antikörpern fuer die IgGSubklassen und lobte die hohe Spezifität. Bisher sind aber weder poly- noch monoklonale Antikörper mit definierter Spezifität für sämtliche unterschiedlichen IgG-Subklassen verfügbar (Butler et al. 2009).

\subsubsection{Der Colostrum Quality Counter (CQC)}

In allen Immunoassays besteht grundsätzlich die Gefahr, dass Interferenzen auftreten. Das zu untersuchende Substrat kann spezifisch oder unspezifisch gebunden werden, was dazu führt, dass die Ergebnisse falsch negativ ausfallen oder die Konzentration in der Probe zu niedrig bestimmt wird. Oder die Bindung kann durch andere Substanzen blockiert werden, sodass die Konzentration unterschätzt wird. Nach Angaben des CQC-Herstellers Prionics wurden das Filterpapierverfahren 
und die mAbs gezielt ausgewählt, um Verluste von IgG in der Probe durch unspezifische Bindungsreaktionen zu vermeiden.

Beim CQC wird Vollblut auf eine Filterpapierkarte getropft. Deren Oberfläche wurde zuvor mit einer Substanz beschichtet, die das im Blut enthaltene IgG sofort binden soll, um Verluste zu vermeiden. Solche Verluste können etwa durch heterophile Bindungen an Blutbestandteile, Fibrin oder das Blutentnahmebesteck entstehen. Der Hersteller wirbt mit optimaler Freisetzung von IgG und exakten Resultaten durch niedrige heterophile Bindungsreaktionen. Als Messbereich werden 0,1 bis $100 \mathrm{mg} / \mathrm{ml}$ IgG im Vollblut angegeben. (Prionics, interne Mitteilung).

In der Anleitung für den CQC für Tierhalter werden alle Schritte sorgfältig erklärt. Mögliche Fehlerquellen durch unvollständige Vorbereitung sollen auf diese Weise von vornherein ausgeschaltet werden. Auf die Möglichkeit, dass zu wenig Blut auf die Filterpapierkärtchen gelangt, wird hingewiesen: der Bluttropfen soll auch auf der Rückseite des Kärtchens zu sehen sein. Nach Ankunft der Proben im Labor wird dann gemäss dem ELISA-Protokoll (Anhang 3) vorgegangen. 


\section{Publizierte Studienergebnisse}

\section{Untersuchungen zur postkolostralen Immun- globulin-G-Versorgung neugeborener Saugferkel mittels unterschiedlicher ELISA-Nachweissysteme}

A. Pausenberger; K. Schuster; M. H. Erhard

Lehrstuhl fur Tierschutz, Verhaltenskunde, Tierhygiene und Tierhaltung, Tierarztliche Fakultat der Ludwig-Maximilians-Universitat Munchen

Schlüsselwörter

Schwein, Saugferkel, ELISA-Diagnostik, maternale Antikörper, Immunglobulin $\mathrm{G}$

\section{Zusammenfassung}

Gegenstand und Ziel: Überprüft werden sollte die Anwenderfreundlichkeit, Praxistauglichkeit und Vergleichbarkeit der Ergebnisse des $\mathrm{Co}$ lostrum Quality Counter (CQC), einer neuen Untersuchungsmethode für die postkolostrale Immunglobulin-G-(IgG-)Versorgung beim Saugferkel. Material und Methode: Blutproben von insgesamt 219 Saugferkeln aus vier Betrieben wurden mit drei verschiedenen ELISA-Testsystemen auf ihre lgG-Konzentrationen untersucht. Bei 30 Saugferkeln wurden darüber hinaus die lgG-Konzentrationen aus zentralvenös und peripher entnommenem Blut mit zwei Testsystemen bestimmt und verglichen. Zum Einsatz kamen der Colostrum Quality Counter (CQC, FarmulaONE, NL-Best), der interne IgG-ELISA des eigenen Lehrstuhls (MUC) und ein kommerziell erhältlicher IgG-ELISA (NAT; NatuTec, Frankfurt/Main). Ergebnisse: Die Einzelwerte aller drei Tests wichen deutlich voneinander ab, wobei MUC und NAT deutlich höhere Korrelationen zueinander aufwiesen als zum CQC. Die Messwerte des CQC lagen insgesamt deutlich höher und wiesen eine wesentlich größere Streuung auf. Die aus zentralvenösem und peripherem Blut ermittelten Messwerte differierten nicht signifikant. Klinische Relevanz: Der CQC ermöglicht eine einfache Probennahme auch bei größeren Strichprobenzahlen. Die Ergebnisse waren individuell sehr unterschiedlich mit einigen ungewöhnlich hohen Werten. MUC und NAT lieferten miteinandervergleichbare Messresultate und die bestimmten IgG-Konzentrationen zeigten eine deutliche Korrelation zueinander.

\section{Key word}

Swine, suckling piglets, ELISA diagnostics, maternal antibodies, immLnoglobulin $\mathrm{G}$

\section{Summary}

Objective of the study was to evaluate whether the Colostrum Quality Counter (CQC), a new test method for immunoglobulin $\mathrm{G}(\mathrm{lgG})$ levels in newborn piglets, is easy to handle and provides comparable results to established testing regimes. Material and methods: Blood samples from 219 piglets from four different farms were tested for their lgGconcentrations using three different ELISA tests. Furthermore, double samples from 30 piglets were taken from both the anterior vena cava and from the tail to determine whether the collection site affects the results. The three tests used were the Colostrum Quality Counter (CQC: FarmulaONE, NL-Best), the internal IgG-ELISA from our laboratory (MUC) and a commercially-available IgG-ELISA (NAT; NatuTec, Frankfurt/Main, Germany). Results: MUC and NAT showed a higher correlation to each other than to the $C Q C$ when referring to the individual results per single piglet. The results from the CQC were higher and the standard deviation was significantly greater. The sampling site had no significant effect on the IgG concentrations measured. Clinical relevance: The $C Q C$ is a straightforward and simple test, being very convenient for sampling a large number of piglets. $C Q C$ results were inhomogeneous with some unusually high IgG-concentrations. MUC and NAT provided comparable results to one another and the lgG-concentrations showed a good correlation.
Korrespondenzadresse

Astrid Pausenberger

Abtstraße 12

80807 Munchen

E-Mail: pausiemausie@arcorde
Investigation on the immunoglobulin $\mathrm{G}(\mathrm{lg} \mathrm{G})$ levels in newborn piglets by use of three different EUSA tests

Tierärztl Prax 2012; 40 (G): 77-84

Eingegangen: 26. August 2011

Akzeptiet nach Revision: 4. Januar 2012

\section{Einleitung}

Schweine haben eine epitheliochoriale Plazenta, weshalb Ferke weitgehend ohne maternale Antikörper geboren werden. Die Versorgung der Neugeborenen mit Immunglobulinen erfolgt fast ausschließlich über das Kolostrum. Die Aufnahme von Kolostrum ist damit für die Ferkel überlebenswichtig. Es liefert den Neonaten spezifische Antikörper von der Sau, deren Qualităt und Quantität von unterschiedlichen Faktoren abhängen $(6,7,25)$.
Einer der wichtigsten Leistungsparameter in der Ferkelproduktion ist die Anzahl der verkauften Ferkel pro Sau und Jahr, die in direkter Korrelation zur Anzahl der Saugferkelverluste steht (13). Je höher die Leistungen eines schweineproduzierenden Betriebs sind, umso wichtiger wird es folglich, die kostspieligen Saugferkelverluste zu minimieren. Die genetisch verankerte höhere Fruchtbarkeitsleistung moderner Sauen erbringt mehr lebend geborene Ferkel, die aber nur als gesunde Absetzferkel verkauft werden und so zum Betriebseinkommen beitragen können. 
Einen wichtigen Beitrag kann eine optimierte Kolostrumversorgung leisten. Verschiedene Studien weisen eine direkte Korrelation der Neugeborenensterblichkeit mit den ImmunglobulinG-(IgG-)Konzentrationen im Plasma nach (13, 14, 29). Die Kolostrumaufnahme beeinflusst aber auch die weitere Lebensleistung, beispielsweise in Form eines besseren Wachstums in der Aufzuchtperiode (22).

Eine anwenderfreundliche Diagnostik zur Überprüfung der Immunglobulinversorgung in der Herde gestaltet sich schwierig. Die Messung der Immunglobulinkonzentration im Ferkelblut mit den bisher verfügbaren Methoden setzt einen venösen Zugang zur Gewinnung von Serum voraus. Die Blutentnahme stellt großen Stress für die Tiere dar, der gerade beim Neugeborenen soweit wie möglich reduziert werden sollte. Jeder Tierbesitzer wird folglich die Anzahl der beprobten Ferkel so niedrig wie möglich halten wollen, was die statistische Aussagekraft der erhobenen Werte negativ beeinflusst.

Die holländische Firma FarmulaONE (NL-Best) hat mit dem Colostrum Quality Counter (CQC) einen Test auf den Markt gebracht, der auf einfache Weise eine Probennahme zur Bestimmung der IgG-Konzentration im Blut von Ferkeln ermöglicht. Dabei wird das Kupieren des Ferkelschwanzes genutzt, um einige Tropfen Blut zu gewinnen, die - auf ein spezielles Filterpapier aufgebracht - zur Durchführung eines Sandwich-ELISA ausreichen (3). Das Kürzen des Schwanzes von unter 4 Tage alten Ferkeln ist laut deutschem Tierschutzgesetz $\$ 5$ Absatz (3) Satz 3 (5) ohne Betäubung gestattet und erfolgt in vielen Ferkelerzeugerbetrieben routinemäßig zur Verhinderung späteren Schwanzbeißens. Der Landwirt muss allerdings nachweisen, dass der Eingriff für die vorgesehene Nutzung des Tieres zu dessen Schutz oder zum Schutz anderer Tiere unerlässlich ist. In den heutigen Intensiv-Aufstallungssystemen ist es laut EFSA-Gutachten (10) „effizienter, den Schwanz bei Ferkeln zu kupieren, da Umgebungsrisiken und eventuelle genetische Gefahrenumstände vorherrschen. " Der Forschungsbedarf wird angesprochen. Nach der Agrarministerkonferenz vom 30. April 2010 in Plön sollen konkrete Handlungsempfehlungen zu den EU-Bestimmungen bezüglich des Schwanzkürzens erarbeitet werden (1).

Mit der IgG-Bestimmung bietet sich eine Kontrollmöglichkeit für den Status quo der Kolostrumversorgung in einem bestimmten Betrieb oder sogar bei einer bestimmten Sauengruppe oder Einzelsau an. Bei einer unbefriedigenden Situation lässt sich ferner durch spätere Untersuchungen feststellen, ob es gelungen ist, durch unterschiedlichste Eingriffe in das Betriebsmanagement die aufgenommene Kolostrummenge zu optimieren. Für Studien und Untersuchungen stellt dieser Test darüber hinaus ein deutlich erleichtertes Verfahren dar, um weitere Einflussfaktoren auf die aufgenommene Kolostrummenge zu eruieren.

Ziel der vorgestellten Untersuchungen war,

- den Einsatz des CQC unter Feldbedingungen zu erproben,

- die Ergebnisse mit denen etablierter Tests zu vergleichen und

- den Zusammenhang zwischen den Resultaten und Gewicht, Geschlecht sowie Alter zu überprüfen.

\section{Tiere, Material und Methoden}

\section{Tierkollektiv und Beprobung}

In vier konventionell arbeitenden Ferkelerzeugerbetrieben (A, B, C aus Bayern und D aus Sachsen) wurden insgesamt 219 verwertbare Blutproben gezogen. In allen Betrieben werden Ferkel herkömmlicher Drei-Rassen-Kreuzungen (Sauen: Deutsche Landrasse $\times$ Deutsches Edelschwein; Eber: Pietrain) erzeugt. Nähere Angaben zu betrieblichen Leistungsdaten, zu Wurfzahl, Trächtigkeit oder Geburtsverlauf wurden nicht dokumentiert.

Sämtliche Ferkel waren zum Zeitpunkt der Beprobung zwischen 1 und 3 Tage alt. Die Blutgewinnung erfolgte im Rahmen der in den jeweiligen Betrieben routinemäßigen Durchführung des Schwanzkupierens. Vom austretenden Blut wurden einige Tropfen auf ein Testfeld eines Filterpapier-Kärtchens (Test CQC, Fa. FarmulaONE, NL-Best; sechs Testfelder pro Kärtchen) getropft und einige Tropfen mithilfe eines heparinbeschichteten Hämatokritröhrchens aufgenommen. Noch im Stall erfolgten die Zentrifugation der unmittelbar nach der Probennahme verschlossenen Röhrchen und das Abpipettieren von $2 \mu \mathrm{l}$ Serum in ein vorab beschriftetes Eppendorf-Röhrchen mit $98 \mu \mathrm{l}$ vorgelegter phosphatgepufferter Salzlösung (PBS).

In der Anleitung des CQC wird davon ausgegangen, dass das Kupieren der Schwänze üblicherweise mit einem Schwanzkupiergerät durchgeführt wird, das mit hoher Temperatur arbeitet und die entstandene Wunde sofort verschließt. Auf diese Weise verliert das Ferkel nur eine geringe Menge an Blut. Vom abgeschnittenen Teil des Schwanzes wird dann die verbrannte Wundfläche mit einem Skalpell abgesetzt und das Restblut auf das Testfeld der Filterpapierkarte gedrückt. Um einige Tropfen mehr Blut für die Serumgewinnung zu erhalten, erfolgte das Schwanzkupieren in der vorliegenden Untersuchung mit einem wurfweise gewechselten Skalpell.

In einem Betrieb wurde bei 30 Ferkeln zusätzlich zu den peripher entnommenen Blutproben im Rahmen der Bestandsdiagnostik (blasse Ferkel, Verdacht auf Eisenmangelanämie) Blut aus der V. cava cranialis gewonnen. Die Tiere befanden sich dabei in Rückenlage und der Einstich erfolgte lateral der Sternumspitze. Aus dem verwendeten Vacutainer wurden einige Tropfen Blut für die IgG-Bestimmung entnommen und auf Filterpapier-Kärtchen getropft bzw. zur Serumgewinnung herangezogen (s. o.).

Nach Trocknung der ausgebreiteten Filterpapier-Kärtchen wurden diese mit Trennblättern separiert, gestapelt, in Plastiktütchen verpackt und zur Untersuchung zur Firma FarmulaOne nach Holland gesandt. Die Eppendorf-Röhrchen mit den Serumproben wurden noch am gleichen Tag für die spätere Untersuchung im eigenen Labor eingefroren.

Jedes Ferkel wurde vor der Blutentnahme gewogen, das Geschlecht und das Alter wurden notiert. 
Tab. 1

Vergleich der drei verwendeten ELISA-Tests

Table 1

Comparison of the three different ELISA tests.

\begin{tabular}{|c|c|c|c|}
\hline & $\begin{array}{l}\text { Hausinterner Schwein- } \\
\text { IgG-ELISA (MUC) }\end{array}$ & $\begin{array}{l}\text { Natutec Schwein- } \\
\text { IgG-ELISA (NAT) }\end{array}$ & $\begin{array}{l}\text { Colostrum Quality } \\
\text { Counter (CQC) }\end{array}$ \\
\hline Material & Serum & Serum & Vollblut \\
\hline Vorbereitung & Auftauen & Auftauen & Eluation \\
\hline Beschichtung & $\begin{array}{l}\text { Kaninchen-anti-Schwein- } \\
\text { IgG }\end{array}$ & Ziege-anti-Schwein-IgG & $\begin{array}{l}\text { monoklonaler Maus-anti- } \\
\text { Schwein-IgG }\end{array}$ \\
\hline Blockierung & $0,5 \%$ Gelatine & $1 \% \mathrm{BSA}$ & $\begin{array}{l}\mathrm{PBS} \text { und } \mathrm{NaCl} \text { mit Tween } \\
20 \text { und } 5 \% \mathrm{BSA}\end{array}$ \\
\hline Konjugat & $\begin{array}{l}\text { Kaninchen-anti-Schwein- } \\
\text { IgG-POD }\end{array}$ & $\begin{array}{l}\text { Ziege-anti-Schwein-lgG- } \\
\text { POD }\end{array}$ & $\begin{array}{l}\text { monoklonaler Maus-anti- } \\
\text { Schwein-IgG-POD }\end{array}$ \\
\hline Substrat & TMB & TMB & TMB \\
\hline Stopplösung & $1 \mathrm{M} \mathrm{H}_{2} \mathrm{SO}_{4}$ & $2 \mathrm{M} \mathrm{H}_{2} \mathrm{SO}_{4}$ & $0,5 \mathrm{M} \mathrm{H}_{2} \mathrm{SO}_{4}$ \\
\hline
\end{tabular}

$\mathrm{BSA}=$ bovines Serum-Albumin, POD = Peroxidase (Meerrettichperoxidase), TMB = Tetramethylbenzidin

\section{Labormethoden}

Im eigenen Labor erfolgte eine vergleichende Untersuchung der Serumproben mit zwei IgG-Testsystemen. Zum Einsatz kamen der hausinterne IgG-ELISA (MUC) sowie ein kommerzieller Testkit der Firma NatuTec, Frankfurt/Main ${ }^{1}$ (NAT). Die auf Filterpapier getrockneten Blutproben wurden von der Firma FarmulaONE in Holland mit dem Colostrum Quality Counter (CQC) untersucht.

Alle Tests basieren auf dem Prinzip des ELISA: Das Antigen wird direkt (CQC) oder indirekt durch einen IgG-spezifischen Antikörper (MUC, NAT) auf einer Mikrotiterplatte gebunden und das zu untersuchende Serum in einer Verdünnungsreihe zugegeben. Nach Zusatz eines enzymmarkierten IgG-spezifischen Antikörpers zum entstandenen Antigen-Antikörper-Komplex kann aus der Extinktionsänderung anhand einer IgG-Standardverdünnungsreihe die Antikörperkonzentration bestimmt werden.

Wesentliche Unterschiede der drei Tests bestehen zum einen in der Verwendung verschiedener Antikörper ( $\$$ Tab. 1): Der hausinterne IgG-ELISA MUC nutzt polyklonale Kaninchenanti-Schwein-IgG-Antikörper, der NAT polyklonale Ziege-antiSchwein-IgG-Antikörper, während beim CQC spezifische monoklonale Maus-Antikörper Verwendung finden. Als Probenmaterial dient im CQC Vollblut, im MUC und im NAT Serum. Darüber hinaus wird beim MUC und NAT sofort nach dem Auftauen der Probenbehälter mit dem Test begonnen, während die Probenmaterialien für den $\mathrm{CQC}$ zunächst aus dem Filterpapier gelöst werden müssen. Dies geschieht durch Ausstanzen einer definierten Fläche aus den Testfeldern der Kärtchen. Aus diesen mit getrocknetem Blut getränkten Stanzen wird mithilfe eines Eluationspuffers (Verdünnungspuffer $+0,8 \%$ EDTA) das Probenmaterial ausgewaschen und verdünnt. Die so gewonnene Flüssigkeit stellt das Untersu-

Der Testkit ist heute über die Firma Biomol zu beziehen (www.biomol.de). chungsgut für den ELISA dar. Die photometrische Messung erfolgt in allen Tests bei $450 \mathrm{~nm}$.

\section{Statistische Auswertung}

Die statistische Auswertung führte das statistische Beratungslabor des Instituts für Statistik der Ludwig-Maximilians-Universität München durch. Errechnet wurden das arithmetische Mittel, die Standardabweichung, der Rangkorrelationskoeffizient nach Spearman sowie die Signifikanzen. Das Signifikanzniveau lag bei $\mathrm{p}<0,05$.

\section{Ergebnisse}

Vergleich der IgG-Konzentrationen aus peripher und zentralvenös entnommenem Blut

Bei keinem der beiden Tests bestanden signifikante Unterschiede zwischen den IgG-Konzentrationen der beiden Blutentnahmestellen (\Tab. 2). Der Rangkorrelationskoeffizient nach Spearman zwischen den Proben aus Vene und Schwanz lag beim CQC mit $0,95$ ( $p<0,001)$ deutlich höher als beim MUC mit $0,63(p<0,001)$ ( Abb. 1). Damit bestätigte der CQC auch stark vom Mittelwert abweichende Werte.

Auffallend war der deutlich größere Wertebereich des CQC im Vergleich zum MUC, was sich in der höheren Standardabweichung niederschlägt.

\section{Vergleich der IgG-Einzelwerte}

In die Gesamtauswertung gingen nur Daten aus peripher gewonnenen Blutproben ein. Insgesamt konnten 219 Proben ausgewertet werden. Da die mittels MUC und CQC bestimmten Werte sehr große Unterschiede zeigten, wurden die Proben zusätzlich mit 
Tab. 2 lgG-Konzentrationen (Mittelwert \pm Standardabweichung) in Abhängigkeit von der Lokalisation der Blutentnahme $(n=30)$

Table 2 IgG concentration (mean \pm standard deviation) depending on the location of blood sampling $(n=30)$.

\begin{tabular}{|c|c|c|}
\hline & $\begin{array}{l}\text { Interner IgG-ELISA } \\
\text { (MUC) }\end{array}$ & $\begin{array}{l}\text { Colostrum Quality } \\
\text { Counter (CQC) }\end{array}$ \\
\hline Vene: lgG (mg/ml) & $9,60 \pm 3,30$ & $20,36 \pm 21,45$ \\
\hline Schwanz: IgG (mg/ml) & $9,29 \pm 3,83$ & $21,05 \pm 20,67$ \\
\hline $\begin{array}{l}\text { Korrelationskoeffizient } \\
\text { nach Spearman } \\
\text { (Schwanz/Vene) }\end{array}$ & $0,63(p<0,001)$ & $0,95(p<0,001)$ \\
\hline
\end{tabular}

dem kommerziell erhältlichen IgG-ELISA NAT untersucht. Der NAT bestätigte eindeutig die mit dem MUC erhaltenen Werte (\Tab. 3).

Die mit NAT und MUC gemessenen Konzentrationen mit einem Durchschnittswert von 18,9 bzw. 20,6 mg/ml bewegten sich weitgehend im gleichen Bereich bei ähnlicher Standardabweichung von 8,0 bzw 7,8, während der CQC einen Durchschnittswert von $34,5 \mathrm{mg} / \mathrm{ml}$ mit einer Standardabweichung von 27,2 ergab. Auch Minima und Maxima von NAT und MUC erreichten ähnliche Werte, während der CQC sowohl im Minimum niedriger als auch im Maximum höher lag.

Bei Betrachtung der Einzelwerte aus den drei Tests errechneten sich unterschiedliche Korrelationskoeffizienten nach Spearman. MUC und NAT korrelierten mit 0,65 $(\mathrm{p}<0,001)$ am stärksten miteinander. Die Korrelation zum CQC betrug 0,43 (NAT) $(p<0,001)$ bzw. 0,39 (MUC) $(\mathrm{p}<0,001)$. Die Korrelationen der drei Tests zueinander sind in $>$ Abbildung 2 graphisch dargestellt. Der enorm große Wertebereich der CQC-Ergebnisse wird bei dieser Betrachtung erneut deutlich.

\section{Zusammenhang zwischen IgG-Konzentration und Alter, Geschlecht sowie Gewicht}

Der größte Anteil der untersuchten Ferkel $(\mathrm{n}=139)$ war zum Zeitpunkt der Untersuchung bereits 3 Tage alt, 36 Ferkel waren erst einen
Tab. 3 Mittlere lgG-Konzentration $(\mathrm{mg} / \mathrm{ml})$ sowie Minimal- und Maximalwert in den drei Testsystemen $(n=219)$

Table 3 Mean $\mathrm{lgG}$ concentrations $(\mathrm{mg} / \mathrm{ml})$, minimum and maximum of the three test systems $(n=219)$.

\begin{tabular}{|c|c|c|c|}
\hline & MUC & NAT & CQC \\
\hline Mittelwert \pm SD & $18,9 \pm 8,0$ & $20,6 \pm 7,8$ & $34,5 \pm 27,2$ \\
\hline Minimum & 1,5 & 1,9 & 0,9 \\
\hline Maximum & 48,5 & 46,3 & 129,4 \\
\hline
\end{tabular}

Tag alt und 44 Ferkel wurden am 2. Lebenstag untersucht. Das Gewicht differierte an den verschiedenen Lebenstagen nicht signifikant.

Die mittels MUC und NAT ermittelten durchschnittlichen IgGKonzentrationen weichen nur geringfügig voneinander $a b$. Die Mittelwerte des CQC fielen bei hoher Standardabweichung mit zunehmendem Alter ab. So lag die durchschnittliche IgG-Konzentration der Ferkel am 1. Lebenstag beinahe doppelt so hoch wie die der 3 Tage alten Tiere ( $\$$ Tab. 4). Das Alter war nur im CQC signifikant zur IgG-Konzentration korreliert. Geschlechtsabhängige Unterschiede der IgG-Konzentration ließen sich nicht nachweisen. NAT und CQC zeigten einen signifikanten Zusammenhang zwischen Gewicht und IgG-Konzentration.

\section{Vergleich von Würfen untereinander}

Um eine Aussage darüber zu treffen, ob die Ergebnisse eher zwischen einzelnen Ferkeln oder eher zwischen den Würfen differieren, wurden in Betrieb B die wurfbezogenen Durchschnittswerte und Standardabweichungen für 10 gleichmäßige Würfe mit jeweils acht beprobten Ferkeln ermittelt ( $\$$ Tab. 5 ).

Die wurfweise betrachteten IgG-Durchschnittskonzentrationen schwankten zwischen $15,2 \mathrm{mg} / \mathrm{ml}$ und $31,5 \mathrm{mg} / \mathrm{ml}$ (MUC) bzw. zwischen $13,8 \mathrm{mg} \mathrm{IgG} / \mathrm{ml}$ und $28,8 \mathrm{mg} \mathrm{IgG} / \mathrm{ml}$ (NAT) bei Standardabweichungen im einstelligen Bereich. Im CQC war die größere Schwankungsbreite der gemessenen IgG-Konzentrationen auch bei

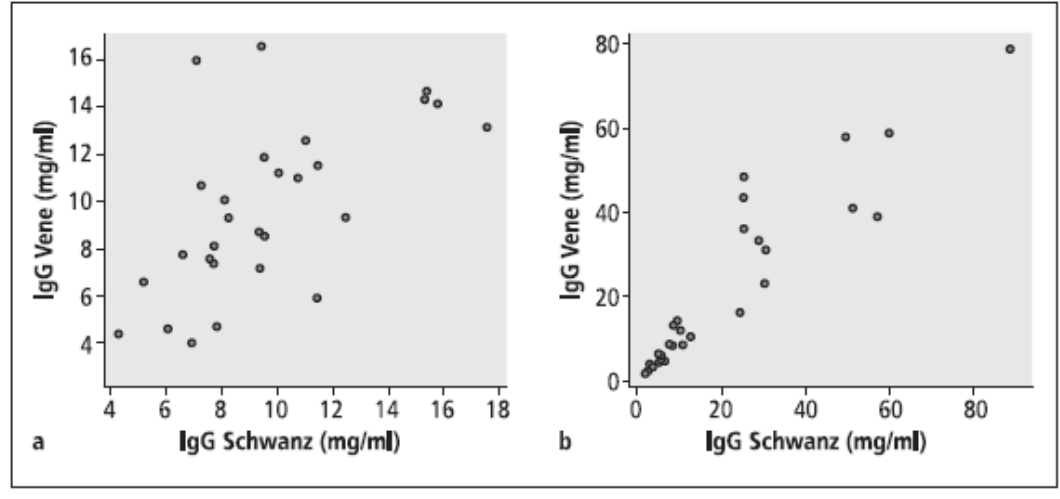

Tierärztliche Praxis Großtiere 2/2012
Abb. 1

Korrelation der IgG-Konzentrationen in zentralvenösem (V. cava cranialis) und peripherem Blut (Schwanz) in den IgG-ELISAs a) CQC (Colostrum Quality Counter) und b) MUC (IgG-ELISA des eigenen Lehrstuhls)

Fig. 1

Correlation of lgG-concentrations from venous (V. cava cranialis) and peripheral (tail) blood in the IgG-ELISAs a) CQC (Colostrum Quality Counter) and b) MUC (IgG-ELISA from our own laboratory). 


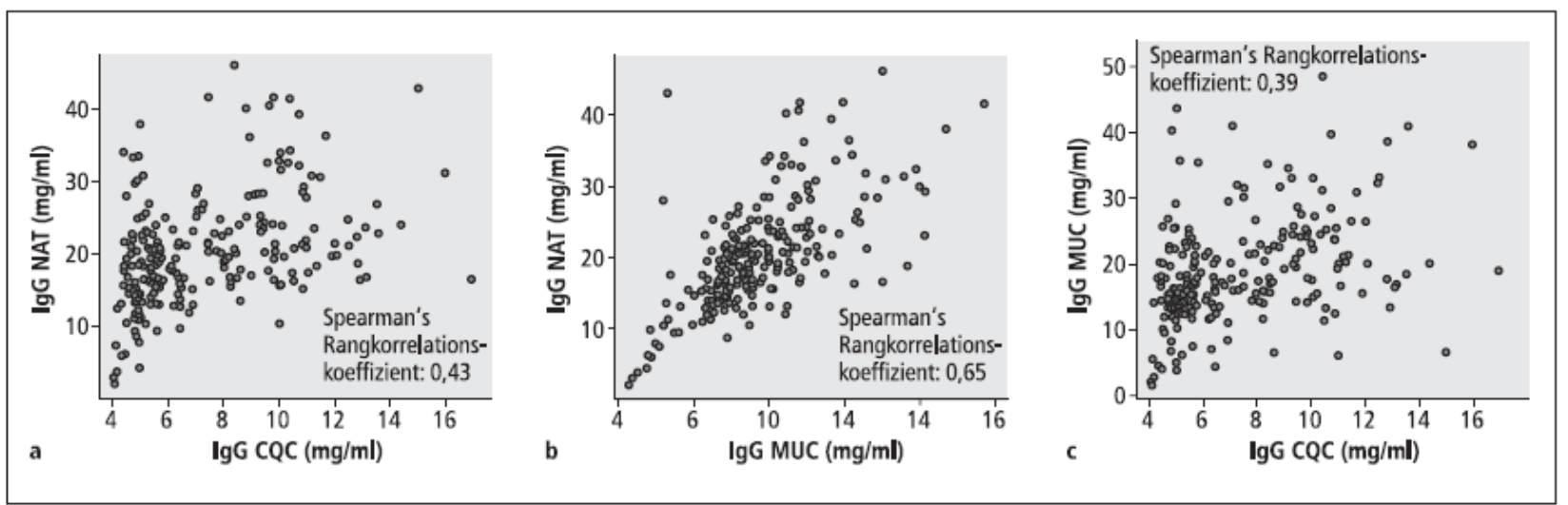

Abb. 2 IgG-Konzentrationen der drei Testmethoden in Korrelation zueinander. a) NAT und CQC; b) NAT und MUC; c) MUC und CQC. NAT = kommerziell erhältlicher IgG-ELISA, CQC = Colostrum Quality Counter, MUC = interner IgG-ELISA des eigenen Lehrstuhls

wurfweiser Auswertung erkennbar. Die beiden Würfe mit den höchsten IgG-Durchschnittskonzentrationen von $64,0 \mathrm{mg} / \mathrm{ml}$ (B3) bzw. 71,8 mg/ml (B10) zeigten auch hohe Standardabweichungen. Hier fanden sich also innerhalb eines Wurfes sehr unterschiedliche Werte. Im Gegensatz dazu wurden bei den Würfen mit niedrigen IgG-Durchschnittskonzentrationen (B1: 7,9 mg/ml, B6: 7,5 mg/ml) auch niedrige Standardabweichungen ermittelt. Das arithmetische Mittel der IgG-Konzentrationen bei Ferkeln aus einem Wurf zeigte bei MUC und NAT eine gute Ubereinstimmung, während im Fall des CQC auch hier deutliche Unterschiede zu verzeichnen waren.

\section{Diskussion}

\section{Praktische Anwendung}

Der CQC wäre für eine Probennahme unter Feldbedingungen sehr gut geeignet. Der Landwirt kann die Probennahme ohne großen

Tab. 4 IgG-Konzentrationen (Mittelwert \pm Standardabweichung) der drei Testsysteme im Vergleich zum Körpergewicht (Mittelwert \pm Standardabweichung) bei unterschiedlichem Lebensalter

Table 4 lgG concentrations (mean \pm standard deviation) of the three detection systems in comparison to the mean body weight and days post natum.

\begin{tabular}{l|l|l|l}
\hline Parameter & Wert & & \\
\hline Alter & $\begin{array}{l}\text { 1 Tag alt } \\
(n=36)\end{array}$ & $\begin{array}{l}\text { 2 Tage alt } \\
(n=44)\end{array}$ & $\begin{array}{l}\text { 3 Tage alt } \\
(n=139)\end{array}$ \\
\hline Gewicht $(\mathrm{kg})$ & $1,82 \pm 0,46$ & $1,66 \pm 0,26$ & $1,87 \pm 0,47$ \\
\hline lgG MUC $(\mathrm{mg} / \mathrm{ml})$ & $22,60 \pm 9,96$ & $17,51 \pm 5,06$ & $18,40 \pm 8,03$ \\
\hline lgG NAT $(\mathrm{mg} / \mathrm{ml})$ & $22,43 \pm 7,71$ & $19,35 \pm 5,13$ & $20,47 \pm 8,42$ \\
\hline lgG CQC $(\mathrm{mg} / \mathrm{ml})$ & $52,09 \pm 26,32$ & $38,99 \pm 29,11$ & $28,48 \pm 24,62$ \\
\hline
\end{tabular}

(C) Schattauer 2012
Fig. 2 Correlation of $\mathrm{IgG}$-concentrations of the three test methods. a) NAT and $C Q C$; b) NAT and MUC; c) MUC and CQC. NAT = commercially available IgG-ELISA, CQC = Colostrum Quality Counter, MUC = internal IgG-ELISA from our own laboratory.

Aufwand in die gewohnten Arbeitsabläufe integrieren. Auf die Tierschutzrelevanz des Schwänzekupierens sei an dieser Stelle nochmals hingewiesen. Die herkömmliche Blutentnahme mit anschließender Serumgewinnung zur Durchführung des MUC ist weitaus aufwendiger. Eine solche Probennahme muss von einem Tierarzt durchgeführt werden und verursacht auch dadurch höhere Kosten. Dem steht beim CQC die mit höherem Aufwand verbundene Aufbereitung der Proben im Labor gegenüber, da das Blut erst aus dem Filterkärtchen ausgewaschen werden muss. Inwieweit sich diese unterschiedlichen Verfahren auf den durch den Tierbesitzer zu zahlenden Endpreis pro Ergebnis niederschlagen, wurde nicht überprüft.

Tab. 5 IgG-Konzentrationen (Mittelwert \pm Standardabweichung) der drei Testsysteme in 10 Würfen des Betriebs $B$ ( $n=8$ pro Wurf)

Table $5 \mathrm{lgG}$ concentrations (mean \pm standard deviation) of the three detection systems in 10 litters of farm B ( $n=8 /$ litter).

\begin{tabular}{|l|l|l|l|}
\hline Wurf & $\begin{array}{l}\text { IgG MUC } \\
(\mathbf{m g} / \mathrm{ml})\end{array}$ & $\begin{array}{l}\text { IgG NAT } \\
(\mathbf{m g} / \mathrm{ml})\end{array}$ & $\begin{array}{l}\text { IgG CQC } \\
(\mathbf{m g} / \mathbf{m l})\end{array}$ \\
\hline B1 & $29,62 \pm 8,98$ & $28,84 \pm 6,44$ & $7,85 \pm 2,58$ \\
\hline B2 & $16,90 \pm 3,63$ & $21,45 \pm 3,69$ & $17,18 \pm 5,01$ \\
\hline B3 & $27,15 \pm 8,73$ & $24,47 \pm 6,75$ & $64,04 \pm 21,72$ \\
\hline B4 & $15,19 \pm 5,63$ & $16,11 \pm 5,20$ & $14,54 \pm 8,17$ \\
\hline B5 & $31,51 \pm 6,43$ & $25,99 \pm 8,51$ & $52,85 \pm 26,46$ \\
\hline B6 & $18,30 \pm 2,91$ & $16,21 \pm 3,19$ & $7,54 \pm 3,49$ \\
\hline B7 & $16,57 \pm 4,17$ & $17,68 \pm 3,87$ & $14,49 \pm 4,97$ \\
\hline B8 & $24,27 \pm 7,76$ & $22,50 \pm 10,25$ & $30,43 \pm 19,26$ \\
\hline B9 & $15,43 \pm 3,74$ & $13,85 \pm 4,09$ & $18,06 \pm 17,61$ \\
\hline B10 & $18,73 \pm 1,44$ & $19,26 \pm 4,24$ & $71,75 \pm 37,88$ \\
\hline $\begin{array}{l}\text { Gesamt } \\
\text { (n=10) }\end{array}$ & $21,37 \pm 6,20$ & $20,64 \pm 4,85$ & $29,87 \pm 24,05$ \\
\hline & & & \\
\hline
\end{tabular}

Tierärztliche Praxis Großtiere 2/2012 


\section{Vergleich der Blutentnahmestellen}

Der bei einer geringen Anzahl Ferkel $(n=30)$ durchgeführte Vergleich der beiden Blutentnahmestellen (Vena cava cranialis bzw. abgesetzter Schwanz) zeigte sehr gute Übereinstimmungen. Bemerkenswert daran ist, dass der CQC auch ungewöhnlich hohe Messwerte zuverlässig bestätigte, was darauf schließen lässt, dass es sich hierbei nicht um einzelne Messfehler handelte.

\section{Direkter Vergleich der drei Nachweissysteme}

Zwischen den Tests bestehen signifikante Korrelationen von 0,65 bzw. 0,43 und 0,39. Unter der Berücksichtigung, dass die gleichen Proben auf den gleichen Inhaltsstoff untersucht wurden, erscheinen die Unterschiede zwischen dem CQC und den anderen beiden ELISAs auf Einzelwerte bezogen ungewöhnlich groß. Der Mittelwert des CQC liegt deutlich höher als diejenigen von MUC und NAT. Bemerkenswert sind auch der weitaus größere Wertebereich und die hohen Standardabweichungen des CQC. Beim Vergleich von Einzelergebnissen liegt der CQC nicht gleichmäßig höher oder niedriger, sondern unregelmäßig gleichauf, höher oder niedriger.

Die Angaben zur IgG-Konzentration beim Ferkel in der Literatur variieren stark, wie $>$ Tabelle 6 zeigt. Zur besseren Ubersicht und Vergleichbarkeit wurden nur Durchschnittswerte aus den jeweiligen Arbeiten herangezogen, Standardabweichungen waren in vielen Fällen nicht verfügbar. Als Probenmaterial diente sowohl Serum als auch Plasma, keine Methode verwendete Vollblut. Das Alter der Ferkel differierte, doch wurden nur solche Untersuchungen berücksichtigt, bei denen die Blutprobenentnahme innerhalb der ersten Lebenswoche erfolgte.

In den aufgeführten Arbeiten liegt der Großteil der IgG-Konzentrationen etwa zwischen 15 und $45 \mathrm{mg} / \mathrm{ml}$. Auch Werte, die mit der gleichen Methode ermittelt wurden, unterscheiden sich zum Teil deutlich. Nielsen et al. (22) nennen Maximalwerte bis zu $76,3 \mathrm{mg} / \mathrm{ml}$, in der Arbeit von Bland et al. (4) findet sich in einer Graphik ein IgG-Wert von etwa $90 \mathrm{mg} / \mathrm{ml}$, der als „anomalously

Tab. 6 Angaben zur IgG-Konzentration bei Ferkeln aus der Literatur Table 6 IgG concentrations of piglets taken from the literature.

\begin{tabular}{|c|c|c|c|c|}
\hline Quelle & $\begin{array}{l}\text { Alter der } \\
\text { Ferkel }\end{array}$ & $\begin{array}{l}\text { Blutentnahme- } \\
\text { stelle }\end{array}$ & Methode zur IgG-Quantifizierung & Substrat / IgG-Konzentration \\
\hline Bland et al. 2003 (4) & 2-7 Tage & $\begin{array}{l}\text { Nabelkatheter/ } \\
\text { V. jugularis }\end{array}$ & Elisa nach Varley (28) & Plasma / 13,6-24,9 mg/ml (MW) \\
\hline Curtis und Bourne 1971 (8) & $24 \mathrm{~h}$ & V. cava cranialis & $\begin{array}{l}\text { single radial immunodiffusion nach Fahey } \\
\text { und McKelley (18) }\end{array}$ & $\begin{array}{l}\text { n. a. / } 18,69-39,06 \mathrm{mg} / \mathrm{ml} \\
\text { (wurfweise MW) }\end{array}$ \\
\hline Frenyo et al. 1980/81 (11) & $24 \mathrm{~h}-120 \mathrm{~h}$ & V. cava cranialis & radiale Immunodiffusion nach Mancini (18) & Serum / 39,45-24,14 mg/ml (MW) \\
\hline Klobasa et al. 1991 (15) & 1-6 Tage & $\begin{array}{l}\text { V. subcutanea } \\
\text { abdominis }\end{array}$ & radiale Immunodiffusion nach Mancini (18) & $\begin{array}{l}\text { Serum / nach } 24 \text { h 23,4-55,1 mg/ml; } \\
\text { nach } 6 \text { Tagen } 14,3-28,5 \mathrm{mg} / \mathrm{ml}(\mathrm{MW})\end{array}$ \\
\hline Klobasa et al. 2004 (16) & $24 \mathrm{~h}$ & $\begin{array}{l}\text { V. subcutanea } \\
\text { abdominis }\end{array}$ & radiale Immunodiffusion nach Mancini (18) & Serum / nach 24 h $39,4 \pm 10,74$ mg/ml \\
\hline Kuhn et al. 2005 (17) & 1-7 Tage & V. cava cranialis & $\begin{array}{l}\text { indirekter, kompetitiver ELISA nach Morrow- } \\
\text { Tesch (20) }\end{array}$ & $\begin{array}{l}\text { Serum / 1. Tag 22,08-25,2 mg/ml (MW); } \\
\text { 7. Tag 13,34-14,87 mg/ml }\end{array}$ \\
\hline Niekamp et al. 2006 (21) & 7 Tage & V. jugularis & ELISA nach Morrow-Tesch (20) & Plasma / 13,2-30,0 mg/ml (MW) \\
\hline Nielsen et al. 2004 (22) & & n. a. & ELISA von DAKO & n. a. $/ 3,9-76,3 \mathrm{mg} / \mathrm{ml}$ \\
\hline Porter 1969 (23) & 2 Tage & V. cava cranialis & radiale Immunodiffusion nach Mancini (18) & Serum / 650-2500 mg/100 ml \\
\hline Rooke et al. 2003 (24) & $24 \mathrm{~h}$ & & & $\begin{array}{l}\text { n. a. / ca. 2-18 mg/ml (geschätzt anhand } \\
\text { Graphik) }\end{array}$ \\
\hline Svendsen et al. 2005 (26) & $27-48 \mathrm{~h}$ & V. cava cranialis & $\begin{array}{l}\text { single radial immunodiffusion nach Fahey } \\
\text { und Mc Kelley (11) }\end{array}$ & $\begin{array}{l}\text { Plasma } / 4,4 \pm 1,9 \mathrm{mg} / \mathrm{ml} \text { bis } \\
37,8 \pm 11,6 \mathrm{mg} / \mathrm{ml}\end{array}$ \\
\hline Tuchscherer et al. 2002 (27) & 1-7 Tage & V. cava cranialis & ELISA nach Morrow-Tesch (20) & $\begin{array}{l}\text { Serum / ca. } 25-45 \text { g/l (geschätzt anhand } \\
\text { Graphik) }\end{array}$ \\
\hline Varley et al. 1985 (28) & 7 Tage & V. cava cranialis & ELISA nach Varley (1985) (28) & Plasma / $10 \pm 0,8 \mathrm{mg} / \mathrm{ml}(\mathrm{MW})$ \\
\hline Werhahn et al. 1981 (30) & 1-3 Tage & $\begin{array}{l}\text { V. subcutanea } \\
\text { abdominis }\end{array}$ & $\begin{array}{l}\text { single radial diffusion nach Fahey und } \\
\text { McKelvey (11) }\end{array}$ & $\begin{array}{l}\text { Serum / bis zu } 45 \mathrm{mg} / \mathrm{ml} \text { (geschätzt } \\
\text { anhand Graphik) }\end{array}$ \\
\hline Yabiki et al. 1974 (31) & 1-3 Tage & n. a. & radiale Immunodiffusion nach Mancini (18) & Serum / 2,040-1,465 mg/dl \\
\hline
\end{tabular}


high “ bezeichnet, aber nicht weiter erläutert wird. Bei IgG-Maximalwerten von deutlich über $100 \mathrm{mg} / \mathrm{ml}$, wie sie in der eigenen Untersuchung mehrfach mit dem CQC gemessen wurden, muss infrage gestellt werden, ob dies bezogen auf die physiologische Gesamtproteinkonzentration realistisch sein kann. Das Fehlen eines echten Goldstandards zur Messung der IgG-Konzentration erlaubt keine sichere Aussage, welche der ermittelten Werte tatsächlich korrekt sind. Allerdings ist zu berücksichtigen, dass sich MUC und NAT mit annehmbarer Korrelation zueinander gut bestätigen und die ermittelten Werte in dem Bereich liegen, der auch in der Literatur angegeben wird.

Inwieweit die Unterschiede zwischen MUC, NAT und CQC auf die verschiedenen Probenmaterialien (Serum vs. Vollblut), die Unterschiede in den Tests (verschiedene Antigen-Antikörper-Systeme), die unterschiedliche Aufbereitung oder auf Messfehler zurückzuführen sind, bleibt ungeklärt. Die Tatsache, dass in unseren Untersuchungen MUC und CQC beim Vergleich der Werte von Proben der beiden Entnahmestellen eine gute Übereinstimmung zeigen, spricht zumindest gegen Messfehler.

\section{Zusammenhang zwischen IgG-Konzentration und Alter, Geschlecht sowie Gewicht}

In anderen Arbeiten wurde der Zusammenhang zwischen Geburtsgewicht und IgG-Spiegel betrachtet. Nielsen et al. (22), Varley et al. (29) und De Passille et al. (9) fanden keinen Zusammenhang, während Klobasa et al. (16) bei höheren Geburtsgewichten auch signifikant höhere IgG-Konzentrationen feststellten. Die Autoren führten das darauf zurück, dass sich stärkere Ferkel bei der Kolostrumaufnahme besser durchsetzen können.

Bezüglich der Abhängigkeit der IgG-Konzentration vom Alter muss bedacht werden, dass die Darmschranke für die Passage der großen IgG-Moleküle nach etwa 24 Stunden geschlossen und die höchste Konzentration erreicht ist $(8,31)$. Das absolute Maximum der IgG-Konzentration wird etwa 12-24 Stunden post natum erreicht $(8,12,15,31)$. Neuere Untersuchungen beim Kalb weisen darauf hin, dass es möglicherweise weitere unterschiedliche Mechanismen für die Resorption der Immunglobulinmoleküle gibt (2), doch für den größten Teil kolostraler IgG-Antikörper dürfte die Resorption innerhalb des ersten Lebenstages vollzogen sein. Etwa zwei Drittel der Gesamtkolostrummenge werden in den ersten 12 Lebensstunden aufgenommen (19), bereits im Verlauf der ersten 24 Stunden nach der Geburt nimmt die IgG-Konzentration im Kolostrum der Sau rapide ab. In den folgenden Tagen sinkt die IgG-Konzentration im Blut der Ferkel durch Verdünnung (Zunahme an Körpermasse und Blutmenge), bis um den 28. Tag ein Minimum erreicht wird $(6,8)$. Ab etwa der $2 . / 3$. Lebenswoche beginnt das Ferkel langsam, selbst Antikörper zu bilden, bis um die 10. Lebenswoche der Blutspiegel erwachsener Tiere erreicht ist $(8,12)$. In unseren Untersuchungen konnten wir das tendenziell insofern bestätigen, als sämtliche Tests die höchsten Werte am 1. Lebenstag ermittelten, während zwischen dem 2. und 3. Lebenstag geringere Unterschiede messbar waren. Einen signifikanten Abfall

\section{Fazit für die Praxis}

Die Untersuchung der IgG-Konzentration im Ferkelblut bietet dem schweineproduzierenden Betrieb die Chance, Probleme bei der Kolostrumversorgung zu erkennen, mögliche Schwachstellen zu identifizieren und letztendlich seine Leistung zu verbessern. Ob die Blutentnahme hierfür direkt zentralvenös oder aus der Peripherie erfolgt, spielt diagnostisch keine entscheidende Rolle. Der CQC wäre grundsätzlich ein praxistaugliches Verfahren zur Überprüfung der Immunglobulinversorgung bei einer größeren Anzahl Ferkel. Bei unseren Untersuchungen ergaben sich bei diesem Test jedoch immer wieder ungewöhnlich hohe lgG-Werte, die nicht schlüssig erklärt werden konnten. Die Abweichungen zu den beiden anderen Testsystemen MUC und NAT waren erheblich, sodass aufgrund der vorliegenden Ergebnisse derzeit auf den Test NAT zurückgegriffen werden sollte. Der MUC ist nicht allgemein verfügbar.

der IgG-Konzentration mit steigendem Alter zeigten allein die mit dem CQC bestimmten Werte. Während beim MUC keine signifikante Korrelation zwischen Alter, Gewicht und IgG-Konzentration bestand, konnten sowohl für den CQC als auch für den NAT signifikante Zusammenhänge zwischen Gewicht und IgG-Konzentration festgestellt werden. Die Resultate von Klobasa et al. (16) ließen sich somit teilweise bestätigen.

\section{Wurfweise/betriebsweise Auswertung}

Die wurfweise Auswertung der IgG-Konzentrationen besitzt die größte Relevanz für die praktische Anwendung in der Schweinepraxis. Probleme bei der Kolostrumversorgung resultieren in schlechteren Tageszunahmen und erhöhten Mortalitätsraten (22, 29) und haben dadurch unmittelbaren Einfluss auf die Wirtschaftlichkeit des Betriebes. Durch eine wurfweise Betrachtung der IgGKonzentration lassen sich Schwachstellen in bestimmten Sauengruppen identifizieren. So könnte etwa die Überprüfung bei zugekauften Jungsauen im Fokus stehen, die dann eine Anpassung von Eingliederungsstrategien oder Impfprogrammen zur Konsequenz hätte.

Die Betrachtung der IgG-Konzentrationen einer größeren Anzahl Ferkel oder mehrerer Würfe erlaubt eine Aussage darüber, wie es um die Kolostrumversorgung im Ferkelbestand des gesamten Betriebes bestellt ist. Wie bei allen Laboruntersuchungen ist dabei zu berücksichtigen, dass bei der Testung unterschiedlicher Betriebe immer der gleiche Test und annähernd die gleiche Stichprobengröße verwendet werden sollten, um die Resultate auch im Vergleich zu anderen Betrieben beurteilen zu können. Ein solcher Vergleich dient nicht nur Forschungszwecken, sondern ist für den praktizierenden Tierarzt wichtig, um eine korrekte Einschätzung treffen zu können.

\section{Interessenkonflikt}

Die Autoren bestätigen, dass kein Interessenkonflikt besteht. 


\section{Literatur}

1. Agrarministerkonferenz: Top 22 Kupieren der Schwånze von neugeborenen Ferkeln, 2010 .

2. Bender $\mathrm{P}$, Bostedt $\mathrm{H}$. Determination of IgG and IgM levels in sera of newborn calves until the 10th day of life by ELISA and description of their correlation to total plasma protein concentration and GGT activity. Dtsch Tierarztl Wochenschr 2009; 116: 44-52.

3. Bianchi ATJ, Moonen-Leusen HW, Bokhout BA. The use of a double antibody sandwich ELISA and monoclonal antibodies for the assessment of porcine IgM, IgG and IgA concentrations. Vet Immunol Immunopathol 1995 44: 309-317.

4. Bland IM, Rooke JA, Bland VC, Sinclair AG, Edwards SA. Appearance of immunoglobulin $\mathrm{G}$ in the plasma of piglets following intake of colostrum, with or without a delay in suckling. Anim Sci 2003; 77: 277-286.

5. BMVEL, Bundesministerium für Verbraucherschutz, Ernăhrung und Tierschutz. Tierschutzgesetz (TierSchG) in der Fassung der Bekanntmachung vom 18.Mai 2006 (BGBl. IS. 1206, 1313), zuletzt geandert durch Artikel 20 des Gesetzes vom 9. Dezember 2010 (BGBl. IS. 1934).

6. Bourne FJ, Newby TJ, Evans P, Morgan K. The immune requirements of the newborn pig and calf. Ann Rech Vét 1978; 9 (2): 239-244.

7. Brambell FW. The transmission of immune globulins from the mother to the foetal and newborn young. Proc Nut Soc 1969; 28: 35-41.

8. Curtis J, Bourne FJ. Immunoglobulin quantitation in sow serum, colostrum an milk and the serum of young pigs. Biochim Biophys Acta 1971; 236 (1): 319-332.

9. De Passille AMB, Rushen J, Pelletier G. Sucking behaviour an serum immunoglobulin levels in neonatal piglets. Anim Prod 1988; 47: 447-456.

10. EFSA - European Food Safety Authority. The risks associated with tail biting in pigs and possible means to reduce the need for tail docking considering the different housing and husbandry systems. The EFSA Journal 2007;611: 1-13.

11. Fahey JL, McKelvey EM. Quantitative determination of serum immunoglobulins in antibody-agar plates. J Immunol 1965; 94: 84-90.

12. Frenyo VL, Pethes G, Antal T, Szabo I. Changes in colostral and Serum IgC content in swine in relation to time. Vet Res Commun 1980/81;4:275-282.

13. Hendrix WF, Kelley KW, Gaskins CT. Hinrichs DJ. Porcine neonatal survival and serum gamma globulins. J Anim Sci 1978; 47: 1281-1286.

14. Klobasa F, WerhahnE, Butler IE. Regulation of humoral immunity in the piglet by immunoglobulins of maternal origin. Res Vet Sci 1981; 31: 195-296.

15. Klobasa F, Werhahn E, Habe F. Untersuchungen uber die Absorption der kolostralen Immunglobuline bei neugeborenen Ferkeln III. Mitteilung: Einfluß der Verabreichungsdauer der Kolostralmilch. Berl Münch Tierărztl Wschr 1991; 104 (7): 223-227.

16. Klobasa F, Schröder C, Stroot C, Henning M. Untersuchungen zur passiven Immunisierung neugeborener Ferkel bei natürlicher Aufzucht - Einflüsse von Geburtsreihenfolge, Geburtsgewicht, Wurfgroße und Wurfnummer Berl Münch Tierărztl Wschr 2004; 117: 19-23.

17. Kuhn G, Ender K, Thomann R, Tuchscherer M, Tuchscherer A, Stabenow B, Krüger M, Schrodl W. Einsatz von Echinacea-Extrakt bei tragenden und săugenden Sauen. Arch Tierz Dummerstorf 2005; 48 (3): 270-282.

18. Mancini G, Carbonara AO, Heremans JF. Immunochemical quantitation of antigens by single radial immunodiffusion. Immunochem 1965;2:235-254.

19. Milon A, Aumaitre A, Le Dividich J, Franz J, Metzger JJ. Influence of birth prematurity on colostrum composition and subsequent immunity of piglets. Ann Rech Vet 1983; 14 (4): 533-540.

20. Morrow-Tesch JL, McGlone JJ, Salak-Johnson JL. Heat and social stress effects on pig immune measures. J Anim Sci 1994; 72:2599-2609

21. Niekamp SR, Sutherland MA, Dahl GE, Salak-Johnson JL. Photoperiod influences the immune status of multiparous pregnant sows and their piglets. J Anim Sci 2006; 84: 2072-2082.

22. Nielsen JP, Kjaersgaard HD, Kristensen CS. Colostrum uptake-effect on health and daily gain until slaughter. Proc. IPVS Hamburg, Germany, 2004 Vol 2.

23. Porter P. Transfer of immunoglobulins IgG, IgA and IgM to lacteal secretions in the parturient sow and their absorption by the neonatal piglet. Biochim Biophys Acta 1969; 181 (2): 381-392.

24. Rooke JA, Carranca C, Bland IM, Sinclair AG, Ewen M, Bland VC. Edwards SA. Relationships between passive absorption of immunoglobulin $\mathrm{G}$ by the piglet and plasma concentrations of immunoglobulin $\mathrm{G}$ at weaning. Livest Prod Sci 2003; 81: 223-234.

25. Rooke JA, Bland IM. The acquisition of passive immunity in the new-born piglet. Livest Prod Sci 2002; 78: 13-23.

26. Svendsen J, Weström BR, Olsson A-Ch. Intestinal macromolecular transmission in newborn pigs: implications for management of neonatal pig survival and health. Livest Prod Sci 2005; 97: 183-191.

27. Tuchscherer M, Kanitz E, Otten W, Tuchscherer A. Effects of prenatal stress on cellular and humoral immune responses in neonatal pigs. Vet Immunol Immunopathol 2002; 86: 195-203.

28. Varley MA, Rucklidge GJ, Wilkinson RJ, Maitland A. Enzyme-linked immunosorbent assay for the measurement of immunoglobulin $\mathrm{G}$ concentrations in porcine plasma and colostrum. Res Vet Sci 1985; 38: 279-281.

29. Varley MA, Wilkinson RJ, Maitland A. Artificial rearing of baby piglets: the effect of colostrum on survival and plasma concentrations of IgG. Brit Vet J 1987; 143: 369 .

30. Werhahn E, Werhahn F, Klobasa F, Butler JE. Investigation of some factors which influence the absorption of IgG by the neonatal piglet. Vet Immuno Immunopathol 1981; 2 (1): 35-51.

31. Yabiki T, Kashiwazaki M, Namioka S. Quantitative analysis of three classes of immunoglobulins in serum of newborn pigs and milk of sows. Am J Vet Res $1974 ; 35: 12$ 


\section{Erweiterte Diskussion}

Die Ergebnisse der Untersuchungen wurden in Teil 3 der vorliegenden Arbeit bereits diskutiert, auf einzelne Punkte soll hier nochmals ausführlicher eingegangen werden.

\subsection{Vergleich unterschiedlicher IgG-Konzentrationen in der Literatur}

In Kap. 3 Tab. 6 werden die ermittelten IgG-Konzentrationen aus unterschiedlichen Studien aufgeführt. Zwar wurde in allen Arbeiten auf das gleiche Substrat hin untersucht, aber die Ergebnisse sind nicht uneingeschränkt vergleichbar, da sich die Fragestellungen und damit der Versuchsaufbau ebenso wie die Methodik sehr unterschiedlich darstellen. In älteren Arbeiten wurde häufiger die radiale Immunodiffusion eingesetzt, heute tendiert man eher zu ELISA-Systemen. Manche Autoren arbeiteten mit Plasma, andere mit Serum. Ob deshalb unterschiedliche Ergebnisse zu erwarten wären, bleibt offen. Die unterschiedlichen Lokalisationen der Blutentnahmen dürften keinen allzu grossen Einfluss haben, wenn man die Erkenntnisse aus der vorliegenden Arbeit hinsichtlich Vene vs. Schwanz berücksichtigt.

Bei allen Einschränkungen ergeben sich für die IgG-Konzentrationen bei Ferkeln innerhalb der ersten Lebenswoche Durchschnittswerte von teilweise unter $10 \mathrm{mg} / \mathrm{ml}$ bis etwa $45 \mathrm{mg} / \mathrm{ml}$ im Serum bzw. Plasma. Nielsen et al. (2004) geben Werte bis 76,3 $\mathrm{mg} / \mathrm{ml}$ an, ein einzelner hoher Wert wird auch bei Bland et al. (2003) erwähnt. In den meisten Arbeiten werden nur Durchschnittswerte betrachtet, allenfalls Standardabweichungen angegeben, es gibt aber weder Minima und Maxima oder Angaben zur Verteilung der Werte.

In den Ergebnissen aus dem CQC lagen 66 von insgesamt 219 Ergebnissen über 50 mg/ml (30\%), davon 12 über $75 \mathrm{mg} / \mathrm{ml}$ und 4 davon sogar ueber $100 \mathrm{mg} / \mathrm{ml}$. Es gab keine auffallenden Häufungen hinsichtlich der Betriebe oder verschiedener Altersgruppen. Abb. 2 veranschaulicht die völlig unterschiedliche Verteilung der Ergebnisse des CQC im Vergleich zu MUC und NAT. Dass $30 \%$ der Werte über $50 \mathrm{mg} / \mathrm{ml}$ liegen, schliesst die Hypothese aus, dass es sich um einzelne 
Fehlmessungen handeln könnte. Dagegen spricht auch die hervorragende Korrelation beim Vergleich der Werte aus Vene und Schwanz (siehe Abb. 1).

Abb. 4: Vergleich der Wertebereiche der drei Testsysteme

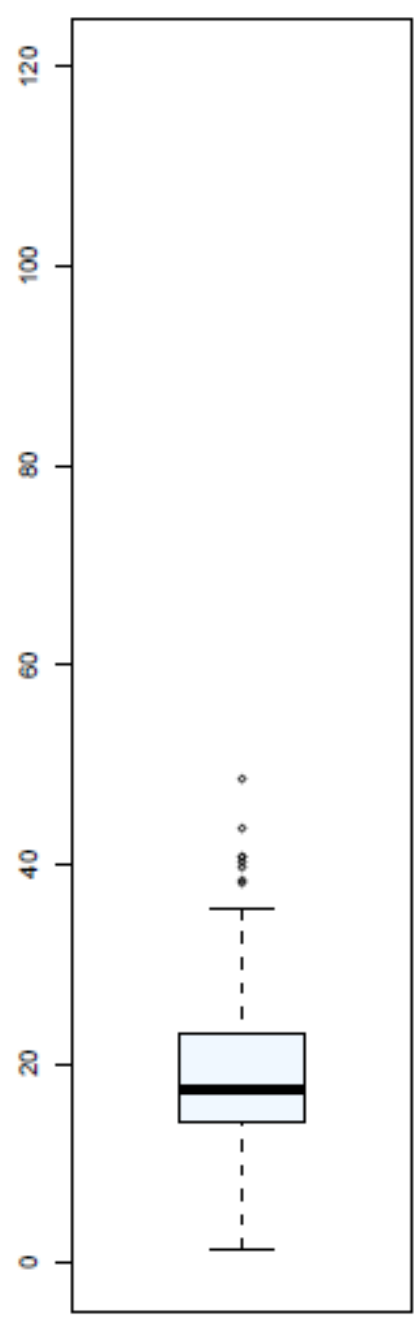

MUC

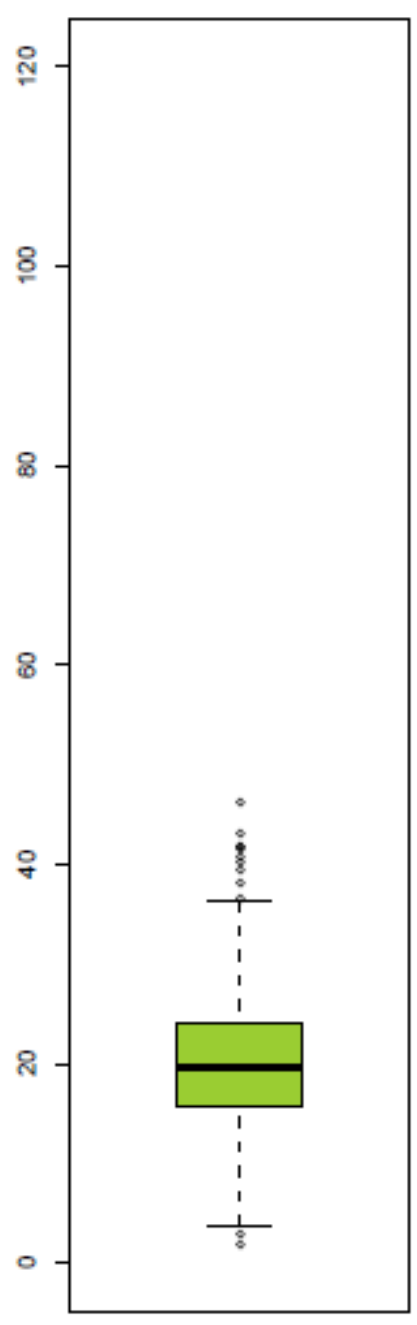

NAT

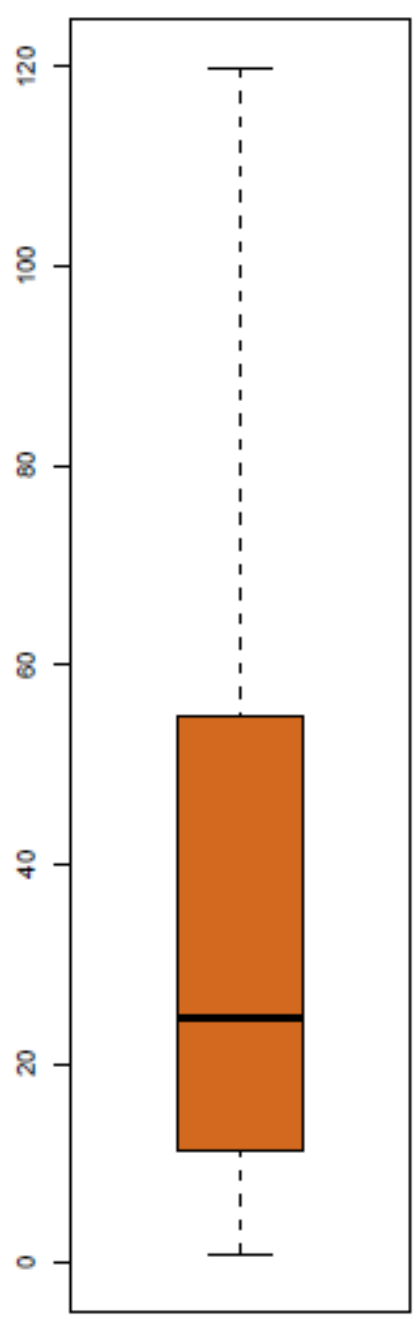

$\operatorname{cQC}$ 


\subsection{Zusammenhänge zwischen IgG-Konzentrationen und Alter, Geschlecht und Gewicht}

In der vorliegenden Arbeit konnte das genaue Alter der Ferkel nicht immer eindeutig ermittelt werden. Auf den Stallkarten der abgeferkelten Sauen waren keine genauen Angaben zum Zeitpunkt der Geburt gemacht, sodass die Möglichkeit besteht, dass manche Ferkel zum Zeitpunkt der Beprobung erst wenige Stunden alt waren, andere dagegen schon eineinhalb Tage. Gerade während des ersten Lebenstages gibt es innerhalb eines Wurfes erhebliche Unterschiede in den individuellen Ig-Konzentrationen (Klobasa et al. 1981, Frenyo et al. 1980/81). Diese potentiellen Variabilitäten mögen sich in der Summe wieder ausgleichen, trotzdem müssen extreme Werte bei so jungen Ferkeln vorsichtig interpretiert werden.

Bemerkenswert bleibt, dass der CQC - anders als MUC und NAT - signifikant höhere IgGKonzentrationen besonders bei den 1-Tag-alten Ferkeln ermittelt wie in Abb. 5 dargestellt. Die 16 sehr hohen Werte aus dem CQC von über $75 \mathrm{mg} / \mathrm{ml}$ stammen aber nicht schwerpunktmässig von den eintägigen Ferkeln, sondern rekrutieren sich recht gleichmässig aus Ferkeln aller drei Altersgruppen.

Abb. 5: arithmetisches Mittel der IgG-Konzentrationen nach Alter in Tagen

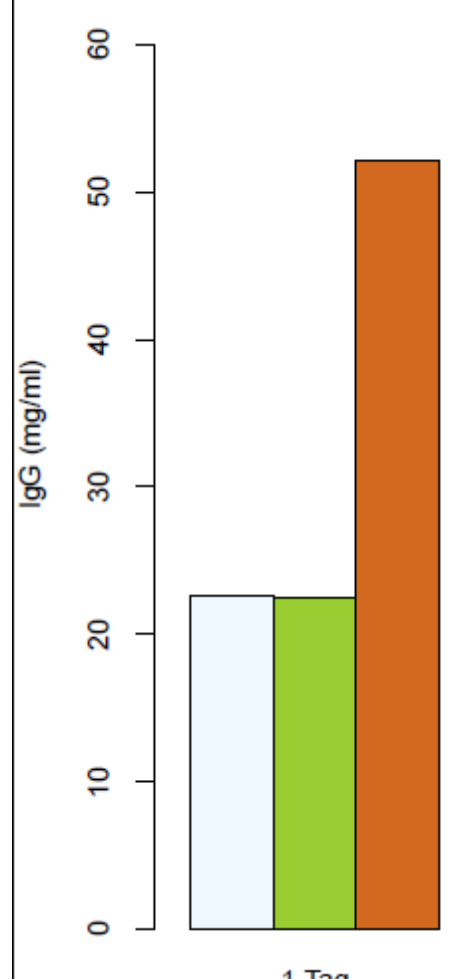

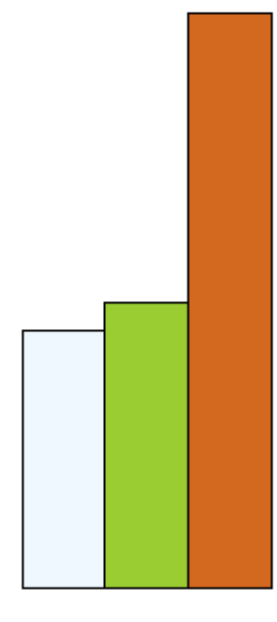

2 Tage
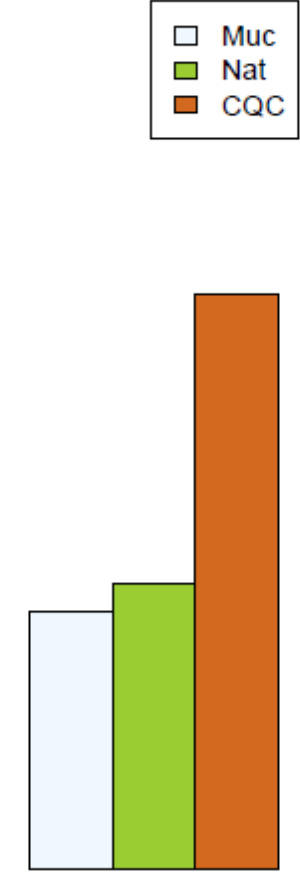

3 Tage 


\subsection{Wurfweise Betrachtung}

Die wurfweise Betrachtung von durchschnittlichen IgG-Konzentrationen pro Wurf ist für die Praxis von grösserer Bedeutung als eine Einzelauswertung. Sie ist ein Indikator für die quantitative Kolostrumproduktion der Sau ebenso wie für die spätere Milchproduktion, weniger aber für die IgG-Konzentration des Kolostrums (DePassille et al. 1988). Die meisten Einflussfaktoren auf die IgG-Konzentration, die von Seiten des Ferkels herrühren, wie Geburtsreihenfolge oder Zitzenpositionen, werden ausgeglichen. Stattdessen erlaubt die wurfweise Betrachtung die Beurteilung einzelner Sauen oder Sauengruppen, was für die Optimierung von Managementmassnahmen von grösserer Bedeutung ist. Eine frühe Bestimmung niedriger Durchschnittskonzentrationen in einem Wurf kann damit helfen, frühzeitig Massnahmen für eine ausreichende Ernährung eines Wurfes zu ergreifen.

Abgesehen vom arithmetischen Mittel sollte dabei auch die Standardabweichung oder die Variabilität der IgG-Konzentrationen innerhalb eines Wurfes berücksichtigt werden. Erwünscht sind homogene Würfe, die gleichzeitig mit gleichmässigen Gewichten abgesetzt werden können. Je grösser die Standardabweichung der gemessenen IgG-Konzentrationen, desto heterologer die IgGVersorgung. Gerade in grösseren Würfen sollte die Verteilung des ohnehin knappen Kolostrums aber möglichst gleichmässig erfolgen. Um die Verteilung zu beurteilen, beschreiben Biermann et al. (2010) den Variationskoeffizienten CV für IgG. Als CV IgG wird die Standardabweichung der IgGKonzentration geteilt durch den Wurfdurchschnitt bezeichnet. In der erwähnten Arbeit, in der der CQC verwendet wurde, werden für zwei Sauengruppen Werte von 49,9 \pm 20,4 bzw. 55,2 \pm 32,2 für den Variationskoeffizienten CV für das Ferkelserum angegeben. Je niedriger CV ist, desto höher ist die Überlebensrate bei gleichen Wurfgrössen.

Bei der Betrachtung von Tab. 5 fällt auf, dass der CQC umso höhere Standardabweichungen innerhalb der Würfe ermittelt, je höher der Mittelwert der IgG-Konzentration ist. Demgegenüber bleiben die Standardabweichungen innerhalb der Würfe bei MUC und NAT recht gleichmässig, unabhängig von der Höhe der Durchschnittskonzentration. Hinsichtlich des CQC sollten folglich auch die Standardabweichungen kritisch betrachtet werden, denn aus der Literatur ist bekannt, dass die Variationen der IgG-Konzentrationen innerhalb eines Wurfes eher gering ausfallen. Auch bei einer hohen Variabilität der Geburtsgewichte waren die IgG-Konzentrationen nicht unterschiedlicher als bei homogenen Würfen (De Passille et al. 1988). 


\subsection{Abweichende Ergebnisse des CQC}

Für den CQC wird mit monoklonalen Antikörpern (mAbs) gearbeitet, es ist also grundsätzlich mit einer höheren Spezifität zu rechnen, als dies für Tests mit polyklonalen Antikörpern (pAb) der Fall ist. Zu erwarten wären damit tendenziell insgesamt höhere oder insgesamt niedrigere Ergebnisse aus dem CQC im Vergleich zu etablierten Testsystemen. In unseren Untersuchungen gab es zwar einen 30\%-igen Anteil von Ergebnissen über $50 \mathrm{mg} / \mathrm{ml} \mathrm{IgG}$, aber die höheren Werte traten nicht gleichmässig und nicht hoch korreliert zu den niedrigeren Ergebnissen aus MUC und NAT auf. Die im CQC gemessenen IgG-Konzentrationen waren ebenso oft deutlich niedriger als diejenigen aus MUC und NAT oder bewegten sich im gleichen Bereich.

\subsection{Abweichungen von der CQC-Anleitung}

Lagerung der Filterpapierkärtchen

Im Protokoll des CQC (Anhang 4) wird empfohlen, die Filterpapierkärtchen bei 2 bis $8^{\circ} \mathrm{C}$ Grad aufzubewahren. In unserer Arbeit wurden die Kärtchen zunächst bei Zimmertemperatur getrocknet, danach verpackt und mit normaler Post nach Holland geschickt. In den ersten Tagen nach Probennahme wurden die Kärtchen folglich bei mehr oder weniger stark abweichenden Temperaturen aufbewahrt.

Menge des aufgebrachten Blutes

Die entstehende Blutung war bei unseren Beprobungen von Ferkel zu Ferkel unterschiedlich stark. Auf das Filterkärtchen wurden immer nur einige Tropfen aufgebracht, eine genaue Dosierung ist unter Stallbedingungen aber nicht möglich und in der Anleitung des CQC so auch nicht vorgesehen. Insgesamt differierte die absolut aufgebrachte Menge zwischen einzelnen Ferkeln aber deutlich. Ein Einfluss auf das Ausbreitungsverhalten des Blutes auf dem Filterpapier ist denkbar. 


\section{Zusammenfassung}

Gegenstand und Ziel: Überprüft werden sollte die Anwenderfreundlichkeit, Praxistauglichkeit und Vergleichbarkeit der Ergebnisse des Colostrum Quality Counter (CQC), einer neuen Untersuchungsmethode für die postkolostrale Immunglobulin-G-(IgG-)Versorgung beim Saugferkel. Material und Methode: Blutproben von insgesamt 219 Saugferkeln aus vier Betrieben wurden mit drei verschiedenen ELISA-Testsystemen auf ihre IgG-Konzentrationen untersucht. Bei 30 Saugferkeln wurden darüber hinaus die IgG-Konzentrationen aus zentralvenös und peripher entnommenem Blut mit zwei Testsystemen bestimmt und verglichen. Zum Einsatz kamen der Colostrum Quality Counter (CQC, FarmulaONE, NL-Best), der interne IgG-ELISA des eigenen Lehrstuhls (MUC) und ein kommerziell erhältlicher IgG-ELISA (NAT; NatuTec, Frankfurt/Main). Ergebnisse: Die Einzelwerte aller drei Tests wichen deutlich voneinander ab, wobei MUC und NAT deutlich höhere Korrelationen zueinander aufwiesen als zum CQC. Die Messwerte des CQC lagen insgesamt deutlich höher und wiesen eine wesentlich größere Streuung auf. Die aus zentralvenösem und peripherem Blut ermittelten Messwerte differierten nicht signifikant. Klinische Relevanz: Der CQC ermöglicht eine einfache Probennahme auch bei größeren Strichprobenzahlen. Die Ergebnisse waren individuell sehr unterschiedlich mit einigen ungewöhnlich hohen Werten. MUC und NAT lieferten miteinander vergleichbare Messresultate und die bestimmten IgG-Konzentrationen waren signifikant zueinander korreliert. 


\section{Summary}

Investigation on the Immunoglobulin G (IgG) levels in newborn piglets

by use of three different ELISA tests

Objective of the study was to evaluate whether the Colostrum Quality Counter (CQC), a new test method for immunoglobulin G (IgG) levels in newborn piglets, is easy to handle and provides comparable results to established testing regimes. Material and methods: Blood samples from 219 piglets from four different farms were tested for their IgG-concentrations using three different ELISA tests. Furthermore double samples from 30 piglets were taken from both the anterior vena cava and from the tail to see whether the collection affects the results. The three tests used were the Colostrum Quality Counter (CQC; FarmulaONE, NL-Best), the internal IgG-ELISA from our laboratory (MUC) and a commercially available IgG-ELISA (NAT; NatuTec, Frankfurt/Main, Germany). Results: MUC and NAT showed a higher correlation to each other referring to the individual results per single piglet than to the CQC. The results from the CQC were higher and the standard deviation was a lot higher. The sampling site had no significant effect on the IgG concentrations measured. Clinical relevance: The CQC is a straightforward and simple test, being convenient for sampling a large number of piglets. CQC results were inhomogenous with some unusual high IgG-concentrations. MUC and NAT provided comparable results to one another and the IgG-concentrations showed a significant correlation. 
ANHANG 1: Protokoll des internen Elisa zum Nachweis von IgG beim Schwein (MUC)

ELISA

Nachweis von Schwein-IgG

letzte Aktualisierung

am

14.09.06Ks

Aktualisiert am 20.03.07Ks

Prinzip: Sandwich

Die Beschichtung erkennt das Schwein-IgG aus der Probe bzw. dem Standard.

Das Konjugat erkennt ebenfalls das Schwein-IgG.

Das Signal ist proportional zur Probe.

Die einzelnen Schritte

Menge/Delle: Inkubation:

1. Beschichtung: $2 \mu \mathrm{g} / \mathrm{ml}$ Rabbit $>\mathrm{Pig} \lg G$

$100 \mu \mathrm{l}$

$4^{\circ} \mathrm{C}$

über Nacht

Stock: (Sigma P8290) 2,6 $\mu \mathrm{g} / \mu \mathrm{l}$

7,7 $\mu$ l Stock in 10ml Beschichtungspuffer / Platte +1/2Platte für Dispensor

WASCHEN

2. Blockierung: $0,5 \%$ Gelatine

$200 \mu \mathrm{l}$

$37^{\circ} \mathrm{C}$ 1h

$100 \mathrm{mg}$ Gelatine in 20m/ PBS / Platte + 1/2Platte für Dispensor

WASCHEN

3. Blank: PBS-T

$50 \mu \mathrm{l}$

$37^{\circ} \mathrm{C} \quad 1 \mathrm{~h}$

Proben: $\quad$ 1:5.000 verdünnt

$100 \mu \mathrm{l}, 50 \mu \mathrm{l} \log 2$

Serum/Plasma

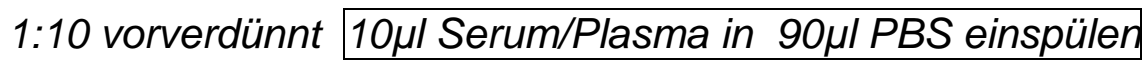

Noch 1:500 verdünnen: 
$2 \mu l$ Probe 1:10v.v. in 1000 $\mu$ l PBS-T einspülen

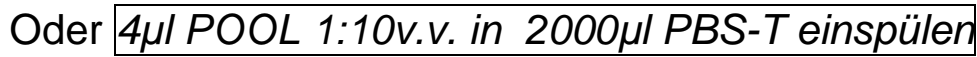

Standard: $\quad 3 \mu \mathrm{g} / \mathrm{ml}$ Pig IgG

$100 \mu \mathrm{l}, 50 \mu \mathrm{l} \log 2$

Stock: (Sigma 14381) $1 \mu \mathrm{g} / \mu \mathrm{l}$

$6 \mu l$ Stock in 2ml PBS-T einspülen

WASCHEN

4. Konjugat: 1:100.000 Rabbit $>$ Pig - IgG-POD

$100 \mu \mathrm{l}$

$37^{\circ} \mathrm{C} \quad 1 \mathrm{~h}$

Stock: (Sigma A5670) 1:100 vorverdünnt

$10 \mu$ l Stock in 10ml PBS-T /Platte + 1/2Platte für Dispensor

TMB-Puffer warm stellen!!!

WASCHEN

5. Substrat: TMB

$100 \mu \mathrm{l}$

dunkel

$10 \mathrm{~min}$

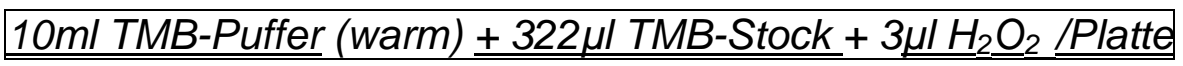

$+1 / 2$ Platte für Dispensor

6. Stopplsg.: $\mathrm{H}_{2} \mathrm{SO}_{4} 1$ molar

$50 \mu \mathrm{l}$

7. Messung: bei $450 \mathrm{~nm}$

Referenzwellenlänge bei 595nm 


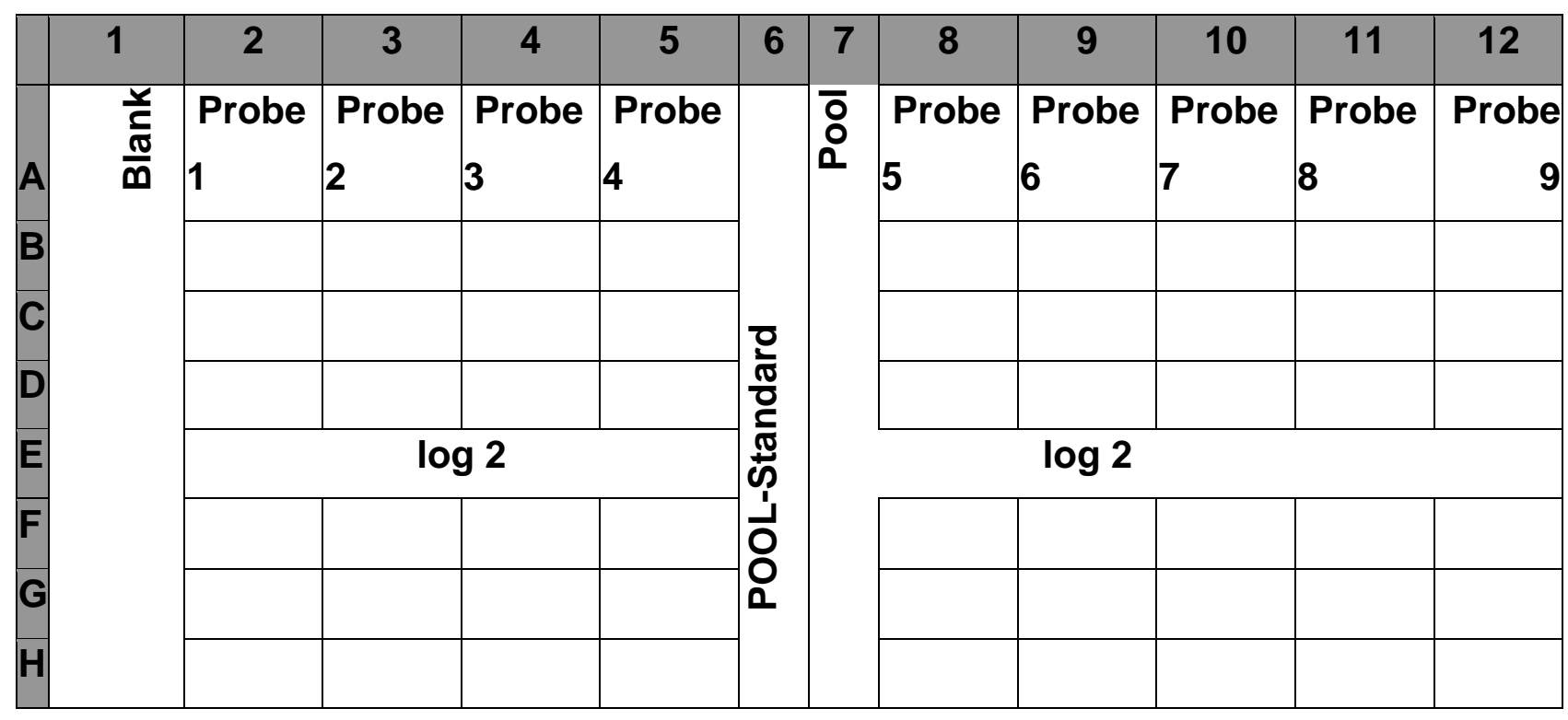


ANHANG 2: Protokoll des NatuTec-ELISA (NAT)

\section{Pig IgG \\ ELISA Quantitation Kit}

\author{
Catalog No. Size \\ E100-104 1000 wells
}

\section{Conditions}

Storage: $2-8^{\circ} \mathrm{C}$

Range of detection: $500-7.8 \mathrm{ng} / \mathrm{ml}$

Shelf life: 1 year from date of receipt

\section{Kit Materials}

1. Coating Antibody

Goat anti-Pig IgG-affinity purified

Concentration: $1 \mathrm{mg} / \mathrm{ml}$

Catalog No: A100-104A

Amount: $1 \mathrm{ml}$

Working Dilution: $1 / 100$

\section{Calibrator}

Pig Reference Serum

Catalog No: RS10-107

Amount: $0.1 \mathrm{ml}$

Working range: $500-7.8 \mathrm{ng} / \mathrm{ml}$

\section{HRP Detection Antibody}

Goat anti-Pig IgG-HRP conjugate

Concentration: $1 \mathrm{mg} / \mathrm{ml}$

Catalog No: A100-104P

Amount: $0.1 \mathrm{ml}$

Working Dilution: 1:10,000-1:200,000

Buffers, Substrate, and Plates not included

\section{Materials Used in Our Assay}

TMB $/ \mathrm{H}_{2} \mathrm{O}_{2}, 50-76-00$, Kirkegaard and Perry, Gaithersburg, $\mathrm{MD}$.

Nunc $C$ bottom Immunoplate 96 well, 446612 .

$1 \%$ Bovine Serum Albumin in Tris Buffered Saline,

T-6789, Sigma Chemical

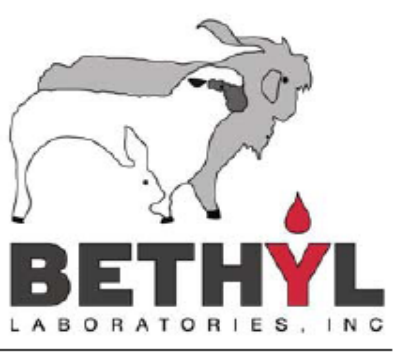

Application

The Pig IgG ELISA is used to quantitatively measure levels of Pig IgG in serum or other biological samples.

\section{Production Procedures}

By immunoelectrophoresis and ELISA the antibodies in this kit react specifically with Pig IgG.

Cross-reactivity with IgG from other species has not been tested.

\section{Notes}

The kit performance has been optimized for the stated protocol using the materials listed and standard dilutions from 500 to $7.8 \mathrm{ng} / \mathrm{ml}$ of Pig IgG. For alternative assay conditions, the operator must determine appropriate dilutions of reagents.

ELISA assay reactivity is sensitive to any variation in operator, pipetting and washing techniques, incubation time or temperature, composition of reagents, and kit age. Adjustments may be required to position the standard curve and/or samples in the desired detection range.

Country of Origin: USA

FOR RESEARCH USE ONLY.

NOT FOR USE IN DIAGNOSTIC PROCEDURES.

\section{Related Products}

$\begin{array}{lr}\text { G x-Pig IgG affinity purified } & \text { A100-104A } \\ \text { G x-Pig IgG HRP conjugate } & \text { A } 100-104 P \\ \text { Pig Reference Serum } & \text { RS10-107 } \\ \text { Pig IgG VET-RID } & \text { R70-100 } \\ \text { ELISA Accessory Starter Kit } & \text { E101 }\end{array}$

ELISA Accessory Starter Kit 


\section{Pig IgG Quantitative ELISA Protocol}

A. Solutions and Reagents

Prepare the following buffers from the ELISA

Starter Accessory Kit (E101) or your lab:
Al. Coating Buffer
0.05 M Sodium Carbonate, $\mathrm{pH} 9.6$
A2. Wash Solution
$50 \mathrm{mM}$ Tris, $0.14 \mathrm{M} \mathrm{NaCl}, 0.05 \%$ Tween 20 , $\mathrm{pH} 8.0$
A3. Blocking (Postcoat) Solution $50 \mathrm{mM}$ Tris, $0.14 \mathrm{M} \mathrm{NaCl}, 1 \%$ BSA, pH 8.0
A4. Sample/Conjugate Diluent $50 \mathrm{mM}$ Tris, $0.14 \mathrm{M} \mathrm{NaCl}, 1 \%$ BSA, $0.05 \%$ Tween 20 , pH 8.0
A5. Enzyme Substrate TMB (OPD or ABTS can be used)
A6. Stopping Solution $2 \mathrm{M} \mathrm{H}_{2} \mathrm{SO}_{4}$ or other appropriate solution

B. Step-by-Step Method (Perform all steps at room temperature.)

B1. Coat with Capture Antibody

a Determine the number of single wells needed. Standards, samples, blanks and/or controls should be analyzed in duplicate. Insert the required number of microtiter well strips into a holder.

a Dilute $1 \mu 1$ capture antibody (A100-104A) to $100 \mu \mathrm{l}$ Coating Buffer for each well to be coated. (Example: for 32 wells dilute $32 \mu 1$ to $3.2 \mathrm{ml}$ )

a Incubate coated plate for 60 minutes.

a After incubation, aspirate the Capture Antibody solution from each well

a Wash each well with Wash Solution as follows:
a Fill each well with Wash Solution
a Remove Wash Solution by aspiration
a Repeat for a total of 3 washes.

B2. Blocking (Postcoat)

a Add $200 \mu 1$ of Blocking (Postcoat) Solution to each well.

a Incubate 30 minutes.

a After incubation, remove the Blocking (Postcoat) Solution and wash each well three times as in Step B1.
B3. - Standards and Samples

- Dilute the standards in Sample Diluent according to the chart below:

\begin{tabular}{|c|c|c|c|}
\hline Step & $\mathbf{n g} / \mathbf{m l}$ & $\begin{array}{c}\text { Calibrator } \\
\text { RS10-107-2 }\end{array}$ & $\begin{array}{c}\text { Sample } \\
\text { Diluent }\end{array}$ \\
\hline 0 & 10,000 & $5 \mu 1$ & $9.1 \mathrm{ml}$ \\
\hline 1 & 500 & $1 \mathrm{ml}$ from step 0 & $19 \mathrm{ml}$ \\
\hline 2 & 250 & $1 \mathrm{ml}$ from step 1 & $1 \mathrm{ml}$ \\
\hline 3 & 125 & $1 \mathrm{ml}$ from step 2 & $1 \mathrm{ml}$ \\
\hline 4 & 62.5 & $1 \mathrm{ml}$ from step 3 & $1 \mathrm{ml}$ \\
\hline 5 & 31.25 & $1 \mathrm{ml}$ from step 4 & $1 \mathrm{ml}$ \\
\hline 6 & 15.625 & $1 \mathrm{ml}$ from step 5 & $1 \mathrm{ml}$ \\
\hline 7 & 7.8 & $1 \mathrm{ml}$ from step 6 & $1 \mathrm{ml}$ \\
\hline
\end{tabular}

a Dilute the samples, based on the expected concentration of the analyte, to fall within the concentration range of the standards.

a Transfer $100 \mu 1$ of standard or sample to assigned wells.

a Incubate plate 60 minutes.

a After incubation, remove samples and standards and wash each well 5 times as in Step B1.

B4. $\square$ HRP Detection Antibody

a Dilute the HRP Conjugate (A100-104P) in Conjugate Diluent. Recommended starting dilution is $1: 100,000$ with a range of $1: 10,000$ to 1:200,000. (Note: Adjustments in dilution may be needed depending on substrate used, incubation time, and age of kit.)

ป Transfer $100 \mu 1$ to each well.

a Incubate 60 minutes.

a After incubation, remove HRP Conjugate and wash each well 5 times as in Step B1.

B5. Enzyme Substrate Reaction

a Prepare the substrate solution according to the manufacturer's recommendation.

a If using TMB from the ELISA Starter Accessory Kit, mix equal volumes of the two-substrate reagents.

a Transfer $100 \mu 1$ of substrate solution to each well.

I Incubate plate 5 - 30 minutes.

a To stop theTMB reaction, apply $100 \mu 1$ of 2 $\mathrm{M} \mathrm{H}_{2} \mathrm{SO}_{4}$ to each well. If using another substrate, use the stop solution recommended by manufacturer.

a Using a microtiter plate reader, read the plate at the wavelength that is appropriate for the substrate used (450 $\mathrm{nm}$ for TMB) 


\section{Calculation of Results}

a Average the duplicate readings from each standard, control, and sample.

a Subtract the zero reading from each averaged value above.

a Create a standard curve by reducing the data using computer software capable of generating a four parameter logistic (4-PL) curve-fit. Other curve fits may also be used.

- A standard curve should be generated for each set of samples (See example below).

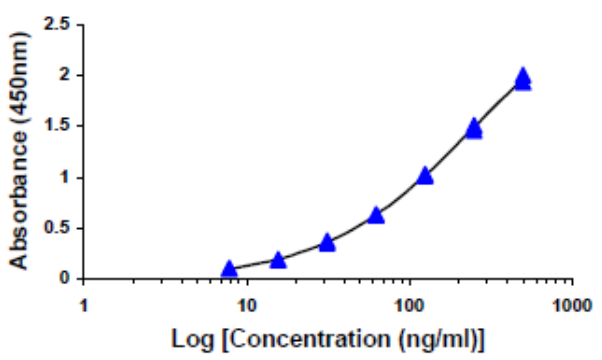

D. Troubleshooting

D1. Problem: Low absorbance

a Incorrect dilutions or pipetting errors

a Improper incubation times

a Improper mixing of the TMB substrate. Each component is mixed in equal parts.

a Wrong filter on microtiter reader. Wavelength should be $450 \mathrm{~nm}$ for TMB, $490 \mathrm{~nm}$ for OPD, or $405 \mathrm{~nm}$ for ABTS.

a Kit materials or reagents are contaminated or expired.

a Incorrect reagents used.

D2. Problem: High Absorbance

a Cross contamination from other samples or positive control

a Incorrect dilutions or pipetting errors

ป Improper washing

a Wrong filter on microtiter reader. Wavelength should be $450 \mathrm{~nm}$ for TMB, $490 \mathrm{~nm}$ for OPD, or $405 \mathrm{~nm}$ for ABTS.

a Contaminated buffers or enzyme substrate

a Improper incubation times

a Kit materials or reagents are contaminated or expired.
D3. Problem: Poor Duplicates

a Poor mixing of specimens

a Incorrect dilutions or pipetting errors

a Technical error

a Inconsistency in following ELISA protocol

a Inefficient washing

D4. Problem: All wells are positive

a Contaminated buffers or enzyme substrate

a Incorrect dilutions or pipetting errors

a Kit materials or reagents are contaminated or expired.

- Inefficient washing

D5. Problem: All wells are negative

a Procedure not followed correctly

a Contaminated buffers or enzyme substrate

a Contaminated Conjugate

a Kit materials or reagents are contaminated or expired.

\section{E. Technical Hints}

a When preparing coating buffer from the gel capsule, break the capsule apart and pour ingredients into water. Do not place gel capsule into water. The gelatin from the capsule interferes with the binding of the coating antibody to the plate.

- Capture antibody diluted with coating buffer should be added to wells immediately.

a Coated (covered) plates are stable overnight at $4^{\circ} \mathrm{C}$.

a Check all buffers for contamination and expiration. When trouble shooting, it may be helpful to start with all new buffers. Make buffers in new or properly cleaned vessels.

a Sodium Azide should not be added to any of the buffers.

a Dilutions should be made shortly before application and immediately applied to appropriate wells.

a Wash buffer should be aspirated from wells Pouring/Dumping wash buffer from wells may lead to cross contamination.

a Excess antibody/analyte should be wiped from pipettes tips when making dilutions.

a Incubation time of the Enzyme Substrate will depend on the substrate used and the intensity of the color change. The high standard should have an O.D. reading of about 2.0 and the O.D. reading of the low standard should be above background.

a Stop solution should be added to the plate in the same order as the Enzyme Substrate. 
Pig IgG

ELISA Quantitation Kit

Catalog No. Size

E100-104 1000 wells

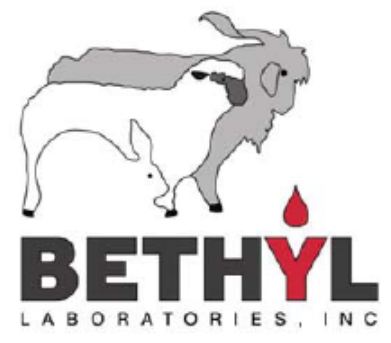

\section{MATERIAL SAFETY DATA SHEET}

\section{Contents Description}

This product contains sheep or goat affinity purified antibody, sheep or goat HRP conjugated affinity purified antibody and reference serum.

\section{Hazardous Ingredients}

Affinity Purified Antibody - No known toxicity for this biological material.

Reference Serum - No known toxicity for this biological material.

Horseradish Peroxidase (HRP)- No known toxicity for this plant material.

Bovine Serum Albumin (BSA) - No known toxicity for this biological material.

Thimerosal - May be fatal if inhaled, swallowed or absorbed through the skin. Can cause eye and skin irritation. Wash all affected areas with large volumes of water. If swallowed consult your physician immediately. If inhaled remove to fresh air. If necessary, give artificial respiration by mouth-to mouth LD50 oral rat $-75 \mathrm{mg} / \mathrm{kg}$.

Sodium Azide $\left(\mathrm{NaN}_{3}\right)$ - AZIDE FORMS EXPLOSIVE CHEMICAL COMPOUNDS WITH LEAD AND COPPER PLUMBING. CARE MUST BE TAKEN TO WASH WASTE DOWN DRAINS WITH LARGE VOLUMES OF WATER.

LD50 oral mouse $-27 \mathrm{mg} / \mathrm{kg}$.

Wash all affected areas with large volumes of water and if swallowed consult your physician immediately.

The above information is believed to be correct but does not purport to be all-inclusive and is intended to be used only as a guide. Bethyl Laboratories, Inc. shall not be liable or responsible in any way for use of either this information or the material supplied. Disposal of hazardous material may be subject to federal, state, or local laws or regulations. 
ANHANG 3: Protokoll des Colostrum Quality Counter (CQC)

\section{Bedarf:}

Verbrauchsartikel:

CQC ELISA kit $\quad$ (Prionics Lelystad)

- $\quad$ Kontrolle serum $16.5 \mathrm{mg} / \mathrm{ml}$ : $\quad$ (ITK Diagnostics BV, Cat. No. RS10-107 (Prionics)

Und die üblichen Materialien von einem Labor.

\section{Probenmaterial:}

- $\quad$ Blut von kupierten Schwänzen auf Filterkarten getropft

- $\quad$ Die Filterkarten mit dem Material sollen bei $2-8^{\circ}$ aufbewahrt werden

\section{Arbeitsmethode:}

\section{Vorbereitungen:}

- Alle Reagentien 2 Stunden vor Testbeginn aus dem Kühlschrank holen und auf 22-27 Raumtemperatur erwärmen lassen

- Waschkonzentrat: Jedes Mal frisch zu machen! Die Waschlösung auf 1:200 verdünnen (2ml Waschflüssigkeit und $398 \mathrm{ml}$ gereinigtes Wasser)

- Elutiebuffer ....Puffer): (= Verdünnungspuffer + 0.8\% EDTA):

Verdünnungspuffer 1:5 verdünnen

$\rightarrow \quad$ Verdünningspuffer $5 x$ verdünnen (z.B. $20 \mathrm{ml}$ Verdüunningspuffer $+80 \mathrm{ml}$ aqua purificata)

$\rightarrow \quad 0.8$ gram EDTA

$\rightarrow \quad$ mischen mit magnetischen Mischhilfen

ELISA Puffer: (500ml) Mindestens 2 Stunden vor Beginn oder Übernacht (nicht erwärmen!) $5 \% \mathrm{BSA}+0.05 \%$ Tween $20,2.12 \% \mathrm{NaCl}$ 
$\rightarrow \quad 10.60$ gram NaCl $+250 \mu$ l Tween 20 auflösen in $250 \mathrm{ml} \mathrm{PBS} 13$

$\rightarrow \quad$ Mit Mischmagneten mischen

$\rightarrow \quad 25$ gram BSA zufügen

$\rightarrow \quad 250 \mathrm{ml}$ PBS 13 zufügen

$\rightarrow \quad$ Mit Mischmagneten mischen

(Achtung! Arbeite steril $\rightarrow$ BSA ist ein gutes Nährmittel für Bakterien, deshalb kontrolliere ob der ELISA Puffer nicht verunreinigt ist

- Conjugat: während der ersten Inkubationszeit anmischen:

- 1:1000 $\rightarrow 10 \mu \mathrm{L}$ conjugat $+9.99 \mathrm{ml}$ ELISA-buffer / StabilZym (1:1)

- 1:8000 (1plaat) $\rightarrow 2.25 \mathrm{ml}(1: 1000)+15.75 \mathrm{ml}$ ELISA-buffer / StabilZym (1:1)

(für 2 Platte $\rightarrow 3.14 \mathrm{ml}(1: 1000)+21.98 \mathrm{ml}(1: 1)$

Nach jedes Mal verdünnen mischen mit einem vortex

$\rightarrow$ Auflösung von dem Conjugaat mit 1:1 so dass diese am Ende noch 30 Mal verdünnt werden soll um die Endverdünnung zu bekommen (2 Jahre haltbar;

- Kontrolle:

$10 \mathrm{mg} / \mathrm{ml}:$

$\rightarrow 100 \mu \mathrm{l} \mathrm{lgG}$ Kontrolle Serum $+65 \mu \mathrm{l}$ Rindsblut $=165 \mu \mathrm{L} 10 \mathrm{mg} / \mathrm{ml}$

$1 \mathrm{mg} / \mathrm{ml}:$

$\rightarrow 100 \mu \mathrm{l}(10 \mathrm{mg} / \mathrm{ml})+900 \mu \mathrm{l}$ Rindsblut $=1000 \mu \mathrm{L} 1 \mathrm{mg} / \mathrm{ml}$

- $\quad 30 \mu l$ der Verdünnungen auf eine Karte tröpfeln

- 24 Stunden trocknen an der Luft oder bei $4^{\circ}$

- Kontrollproben in der Tiefkühltruhe aufbewahren

- Vor Gebrauch die Kontrollproben auf Zimmertemperatur erwärmen lassen

Die Proben werden mit Hilfe einer Lochzange aus der Karte gestanzt.

1. Sammle die Proben und Kontrollen von den Karten und setze diese auf eine Platte (Achtung: drehe die Karte auch um, um zu sehen, ob auch genügend Blut auf der anderen Seite ist)

2. Pipettiere $300 \mu$ I Elutiebuffer (sh. Oben) in diese Dummy-Platte

3. Inkubiere die Platte $60 \mathrm{~min}$ bei $37 \pm 1^{\circ} \mathrm{C}$

4. Misch die Verdünnung mit Hilfe einer $100 \mu \mathrm{L}$ - Mulitchannel-Pipette 
5. Lege in eine zweite Dummy-Platte $90 \mu$ I Elutie-Puffer vor. Pipettiere $10 \mu \mathrm{I}$ aus DummyPlatte 1 zu den $90 \mu \mathrm{I}$ in Dummy-Platte 2

6. Lege in eine dritte Dummy-Platte $160 \mu$ I vor und pipettiere $40 \mu \mathrm{I}$ aus Dummy-Platte 2 in die $160 \mu \mathrm{l}$ in Dummy-Platte 3

ELISA:

7. Pipettiere $100 \mu \mathrm{I}$ aus Dummy-Platte 3 in die ELISA-Platte Inkubiere 60 min bei $37 \pm 1^{\circ} \mathrm{C}$ und deck die Platte mit einem Aufkleber ab

8. Verwirf die überschüssige Flüssigkeit und wasche $4 \mathrm{Mal}$ mit ( $\pm 300 \mu \mathrm{L}$ pro Vertiefung).

Vermeide dass die Platte trocken wird ! Nach jedem Mal waschen wird die überschüssige Flüssigkeit verworfen und die Platte vorsichtig aber gründlich auf Papier ausgeklopft.

9. Pipettiere zur Vorbereitung $100 \mu$ I verdünntes monoklonales Konjugat in jede Vertiefung

Inkubiere 60 min bei $37 \pm 1^{\circ} \mathrm{C}$ und decke die Platte mit einem Aufkleber ab

10. Wiederhole Nummer 9.

11. Pipettiere $100 \mu \mathrm{I}$ der Farblösung mit Substrat in jede Vertiefung

15 Minuten bei Zimmertemperatur inkubieren

12. Pipettiere $100 \mu$ I Stoplösung in jede Vertiefung

Vor der Messung vorsichtig schütteln

13 Miss die optische Dichte bei einer Wellenlänge von $450 \mathrm{~nm}$ 


\section{Abkürzungsverzeichnis}

BSA

CQC

ELISA

Ig G/M/A

mAb

MMA

MUC

MW

NAT

p.p.

$\mathrm{pAb}$

PHS

POD

TMB bovines Serum-Albumin

Colostrum Quality Counter von FarmulaONE, NL-Best

Enzyme-linked Immunosorbent Assay

Immunglobulin G/M/A

monoklonaler Antikörper

Mastitis-Metritis-Agalaktie(-Komplex)

interner Schwein-IgG-ELISA des Lehrstuhls für Tierschutz,

Verhaltenskunde, Tierhygiene und Tierhaltung der LMU München

Mittelwert

ELISA zum Nachweis von IgG beim Schwein von Bethyls

Laboratories, zum Zeitpunkt der Probennahme vertrieben über

NatuTec GmbH, Frankfurt, heute erhältlich über Biomol, Hamburg

post partum

polyklonaler Antikörper

peripartales Hypogalaktie(-syndrom)

Meerrettichperoxidase

Tetramethylbenzidin 
Verzeichnis der Abbildungen, Tabellen und Anhänge

\section{Abbildungen}

Abb. 1: Korrelation der IgG-Konzentrationen in zentralvenösem

(V. cava. cranialis) und peripherem Blut (Schwanz) in den IgG-

ELISAS a) CQC und b) MUC 32

Abb. 2: IgG-Konzentrationen der drei Testmethoden in Korrelation zueinander 33

Abb. 3: Pathogenese des peripartalen Hypogalaktiesyndroms (Iben 2000) 12

Abb. 4: Wertebereiche der drei eingesetzten Tests 38

Abb. 5: arithmetisches Mittel der IgG-Konzentrationen nach Alter in Tagen 39

Tabellen

Tab. 1: Vergleich der drei verwendeten ELISA-Tests

Tab. 2: IgG-Konzentrationen (Mittelwert \pm Standardabweichung) in

Abhängigkeit von der Lokalisation der Blutentnahme

Tab. 3: Mittlere IgG-Konzentration (mg/ml) sowie Minimal- und Maximalwert

In den drei Testsystemen

Tab. 4: IgG-Konzentrationen (Mittelwert \pm Standardabweichung) der drei

Testsysteme im Vergleich zum Körpergewicht (Mittelwert \pm Standard-

abweichung) bei unterschiedlichem Lebensalter

Tab. 5: IgG-Konzentrationen (Mittelwert \pm Standardabweichung) der drei

Testsysteme in 10 Würfen des Betrieb B 33

Tab. 6: Angaben zur IgG-Konzentration bei Ferkeln aus der Literatur

\section{Anhänge}

Anhang 1: Protokoll des internen ELISA (MUC) 


\section{Gesamt - Literaturverzeichnis}

Die blauen Ziffern in Klammern markieren die Literaturstellen, die in der Publikation (Kapitel 3) verwendet wurden.

Agrarministerkonferenz 2010: Top 22 : Kupieren der Schwänze von neugeborenen Ferkeln (1)

M Bandrick, M Pieters, C. Pijoan, S K Baidoo, T W Molitor : effect of cross-fostering on transfer of maternal immunity to Mycoplasma hyopneumoniae to pigs. Vet Rec 2011 ; 68 : 100

P Bender, H Bostedt : Determination of IgG and IgM levels in sera of newborn calves until the 10th day of life by ELISA and description of their correlation to total plasma protein concentration and GGT activity 2009 Dtsch Tierärztl Wochenschr 116, 44-52 (2)

B H Berne : Differing Methodology and Equations Used in Quantitating Immunoglobulins by Radial Immunodiffusion - A Comparative Evaluation of Reported and Commercial Techniques. Clin. Chem. 1974 ; 20/1 :61-69

A T J Bianchi, H W M Moonen-Leusen, P J van der Heijden, B A Bokhout : The use of a double antibody sandwich ELISA and monoclonal antibodies for the asissment of porcine IgM, IgG and IgA Concentrations.Vet Immunol immunopathol 1995; 44: 309-317 (3)

J Biermann, J Jourquin, R Van Gelderen, L Goossens: Facilitating nursing behaviour of sows at farrowing has a positive effect on colostrums distribution. Proc. IPVS 2010 Vancouver

I Bland and J A Rooke: Effects of sow, udder section and time on colostrums immunoglobulin G (IgG) concentrations and piglet colostrums intake. Proc. Br. Soc. Anim. Sci. 1998: 158 (abstract)

I M Bland, J A Rooke, V C Bland, A G Sinclair, S A Edwards: The acquisition of IgG from colostrums by piglets. 1999 Proc. Br. Soc. Anim. Sci 189 (abstract) 
I M Bland, J A Rooke, V C Bland, A G Sinclair, S A Edwards Appearance of immunoglobulin $\mathrm{G}$ in the plasma of piglets following intake of colostrum, with or without a delay in suckling. Anim Sci 2003; 77: 277-286 (4)

BMVEL Bundesministerium für Verbraucherschutz, Ernährung und Tierschutz Tierschutzgesetz (TierSchG) in der Fassung der Bekanntmachung vom 18.Mai 2006 (BGBl. l S. 1206, 1313), zuletzt geändert durch Artikel 20 des Gesetzes vom 9. Dezember 2010 (BGBl. 1 S. 1934)

F J Bourne: Studies on colostral and milk whey proteins in the sow 2. The effect of delayed suckling on colostrums and milk whey proteins Anim. Prod 1969; 11: 345-349 (abstract)

F J Bourne, J Curtis: the transfer of immunoglobulins IgG, IgA and IgM from serum to colostrums and milk in the sow. Immunol 1973 24, 157-162

F J Bourne, T J Newby, P Evans and K Morgan: The immune Requirements of the newborn pig and calf. Ann Rech Vét 1978; 9 (2), 239-244 (6)

F W Rogers Brambell: The transmission of immune globulins from the mother to the foetal and newborn young. Proc Nutr Soc 1969; 28: 35-41 (7)

C W Broughton and J G Lecce: Electron-microscopic Studies of the Jejunal Epithelim from Neonatal Pigs Fed Different Diets. J Nutr 1970; 100:445-449

J E Butler, K M Lager, I Splichal, D Francis, I Kacskovics, M Sinkora, N Wertz, J Sun, Y Zhao, W R Brown, R DeWald, S Dierks, S Muyldermans, J K Lunney, P B McCray, C S Rogers, M J Welsh, P Navarro, F Klobasa, F Habe, J Ramsoondar: The piglet as a model for B cell and immune system development. Vet. Immunol. Immunopathol. 2009; 128(1-3): 147-170

J E Butler, Y Zhao, M Sinkora, N Wertz, I. Kacsokovics: Immunoglobulins, antibody repertoire and B cell development. Dev. Comp. Immunol. 2009: 33; p 321-333 
J A Coalson and J G Lecce: influence of nursing intervals on changes in serum Proteins (Immunglobulins) in neonatal pigs. J. Anim. Sc. 1973; 36 /2

J Curtis and F J Bourne: Immunoglobulin quantitation in sow serum, colostrum an milk and the serum of young pigs. Biochim. Biophys. Acta - Prot Struct 1970; 236/1, p 319-332 (8)

A M B De Passille, J Rushen, G Pelletier: Sucking behaviour and serum immunoglobulin levels in neonatal piglets. Anim. Prod. 1988; 47, pp 447-456 (9)

N Devillers, J van Milgen, A Prunier, J LeDividich: Estimation of colostrum intake in the neonatal pig. Anim. Sci. 2004; 78:305-313

N Devillers, C Farmer, J Le Dividich, A Prunier: Variability of colostrums yield and colostrums intake in pigs. Anim. 2007 1:7, 1033-1041

S A Edwards: Perinatal mortality in the pig: environmental or physiological solutions? Livest. Prod. sci. 2002: 78; 3-12

P Ehrlich: Bemerkungen über die Immunität durch Vererbung und Säugung. Dtsch. Med. Wschr. 1892; $18: 511$

EFSA - European Food Safety Authority: The risks associated with tail biting in pigs and possible means to reduce the need for tail docking considering the different housing and husbandry systems. The EFSA Journal 2007; 611: 1-13 n (10)

J L Fahey, E M Mc Kelvey 1973: Quantitative Determination of Serum Immunoglobulins in Antibody-Agar Plates. J. Immunol. 1965; 94/1: 84-90 (abstract) (11)

M H Fahmy: Comparative Study of colostrums and mild compostion of seven breeds of swine. Can. J. Anim. Sci. 1972; 52: 621-627

C. Farmer, P Charagu, M.F. Palin: Influence of genotype on metabolic variables, colostrums and milk composition of primiparous sows. Can. J. Anim. Sci. 2007; 87:511-515 
C. Farmer and H. Quesnel: Nutritional, hormonal and environmental effects on colostrum in sows. J. Anim. Sci. 2009. 87 ( Suppl. 1) 56-65

A Foisnet, C Farmer, C David, H Quesnel: Relationships between colostrums production by primiparous sows and sow physiology around parturition. J. Anim. Sci. 2010; 88: 1672-1683

F Franek: the subclass heterogeneity of Pig IgG. Vet. Immunol. Immunopathol. 1987; 17: 79-89

J Franz and G Corthier: Measurement of porcine faecal IgA, IgG and IgM levels by a competitive enzyme-linked immunosorbent assay. Clin. Exp. Immunol. 1981; 44, 645-649

D Fraser and J Rushen: Colostrum intake by newborn piglets. Can. J. Anim. Sci. 1992. 72: 1-13

V L Frenyo, G Pethes, T Antal, I Szabo: Changes in colostral and Serum IgG Content in swine in relation to time. Vet. Res. Comm.. 1980/81; 4: 275-282 (12)

C Galea, J F Perso, B Ridremont, J Le Dividich, G P Martineau: Field Study into within Litter Variation of passive Immunity in piglets. Proc. of the $18^{\text {th }}$ IPVS 2004 Hamburg

L Göransson: effect of late pregnancy feed. Acta vet. Scand. 1990; 31(1): 109-115 (abstract)

W F Hendrix, K W Kelley, C T Gaskins, D J Hinrichs: Porcine Neonatal Survival and Serum Gamma Globulins. J. Anim. Sci. 1978. 47: 1281-1286 (13)

Herpin P, Le Dividich J, Hulin JC, Fillaut M, De Marco F, Bertin R: Effects of the level of asphyxia during delivery on viability at birth and early postnatal vitality of newborn pigs. J. Anim. Sci. 1996, 74, 2067-2075

B Iben: Das Peripartale Hypogalaktiesyndrom (PHS) der Sau. Grosstierpraxis 2000; 1:4, 18-29 
A R Jensen, J Elnif, D G Duttin, P T Sangild: Development of Intestinal Immunoglobulin Absorption and Enzyme Activities in Neonatal Pigs Is Diet Dependent. J. Nutr. 2001; 131:32593265

F Klobasa, E Werhahn, I E Butler: Regulation of humoral immunity in the piglet by immunoglobulins of maternal origin. Res. Vet. Sci. 1981; 31: 195-296 (14)

F Klobasa, E Werhahn, J E Butler: Composition of sow milk during lactation J. Anim. Sci. 1987. 64:1458-1466

F Klobasa and J E Butler: Absolute and relative concentrations of immunoglobulins G, M and A, and albumin in the lacteal secretion of sows of different lactation numbers. Amer. J. Vet. Res 1987. 48: 176 (abstract)

F Klobasa, J E Butler, F Habe: Maternal-neonatal immunoregulation: suppression of de novo synthesis of IgG and IgA, but not IgM, in neonatal pigs by bovine colostrums, is lost upon storage. Am. J.Vet. Res. 1990 Sep; 51(9): 1407-12 (abstract)

F Klobasa, E Werhahn, F Habe: Untersuchungen über die Absorption der kolostralen Immunglobuline bei neugeborenen Ferkeln III. Mitteilung: Einfluss der Verabreichungsdauer der Kolostralmilch. Berl. Münch. Tierärztl. Wschr., 1991, 104(7):223-7 (15)

F Klobasa, C Schröder, C. Stroot, M. Henning: Untersuchungen zur passiven Immunisierung neugeborener Ferkel bei natürlicher Aufzucht - Einflüsse von Geburtsreihenfolge, Geburtsgewicht, Wurfgrösse und Wurfnummer. Berl. Münch. Tierärztl. Wschr. 2004; 117, $19-23$ (16)

L Krakowski, J Krzyznowski, Z Wrona, K Kostro, A.K.Siwicki: The influence of nonspecific immunostimulation of pregnant sows on the immunological value of colostrums. Vet. Immunol. Immunopathol 2002; 87: 89-95

P E Kruse: The importance of colostral immunoglobulins and their absorption from the intestine of the newborn animals. Ann. Rech. Vet. 1983; 14 (4) 349 - 353 
G Kuhn, K Ender, R Thomann, M Tuchscherer, A Tuchscherer, B Stabenow, M Krüger, W. Schrödl: Einsatz von Echinacea-Extrakt bei tragenden und säugenden Sauen. Arch. Tierz. Dummerstorf 48 (2005) 3, 270-282 (17)

E Lang: Einfluss einer Echinacea-Fütterung auf Immunstatus und Verhalten bei Ferkeln in den ersten Lebenswochen Diss. Med. vet. München 2004

D C Lay, Jr., R L Matteri, J A Carroll, T J Fangman, T J Safranski: Preweaning survival in swine. J. Anim. Sci 2002; 80 (E. Suppl 1): E74-E86

J Le Dividich and J Noblet: Colostrum intake and thermoregulation in the neonatal pig in relation to environmental temperature. Biol Neonate 1981; 40:167-174 (abstract)

J Le Dividich, P Herpin, R M Rosario-Ludovino: Utilization of Colostral Energy by the Newborn Pig. J. Anim. Sci. 1994. 72: 2082-2089

J Le Dividich, G-P Martineau, F Thomas, H Demay, H Renoult, C Homo, D Boutin, L Gaillard, Y Surel, R Bouétard, M Massard: Acquisition de l’immunité passive chez les porcelets et production de colostrums chez la truie. Journ Rech Porc 2004; 36: 451-456

J G Lecce und D O Morgan: Effect of dietary regimen on cessation of intestinal absorption of large molecules (closure) in the neonatal pig and lamb. J. Nutr. 1962; 78:263

N J Lewis and J F Hurnik: The development of nursing behavior in swine. Appl. Anim. Behav. Sc. 1985; 14: 225-232 (abstract)

R Machado-Neto, C N Graves, S E Curtis: Immunoglobulins in piglets from sows heat-stressed prepartum. J. Anim. Sci. 1987; 65: 445-455

G Mancini, A O Carbonara, J F Heremans: Immunochimical quantitation of antigens by single radial immunodiffusion. Immunochem. 1965; 2: 235-254 (18) 
A Milon, A Aumaitre, J Le Dividich, J Franz, JJ Metzger: Influence of birth prematurity on colostrum composition and subsequent immunity of piglets Ann. Rech. Vet. 1983; 14(4): 533-40 (19)

B Morris and R Morris: The effects of corticosterone and cortisone on the uptake of polyvinyl pyrrolidone and the transmission of immunoglobulin $\mathrm{G}$ by the small intestine in young rats. $\mathrm{J}$. Physiol. 1976; 254: 389-403

J L Morrow-Tesch, J J Mc Glone, J L Salak-Johnson: Heat and social stress effects on pig immune measures. J. Anim. Sci. 1994; 72: 2599-2609 (20)

S R Niekamp, M A Sutherland, G E Dahl, J L Salak-Johnson: Photoperiod influences the immune status of multiparous pregnant sows and their piglets.

Journal of Animal Science 2006. 84:2072-2082 (21)

J P Nielsen, H D Kjaersgaard, C S Kristensen: Colostrum uptake-Effect on health and daily gain until slaughter. Proc IPVS Hamburg, Germany, 2004 - Vol 2 (22)

P Porter: Transfer of Immunoglobulins EgG, IgA and IgM to lacteal Secretions in the parturient Sow and their absorption by the neonatal piglet 1969

Biochim. Biophys. Acta 1969; 181 (2): 381-392 (23)

H Prange: Gesundheitsmanagement Schweinehaltung, Ulmer Verlag, 2004

G Reiner, B Hertrampf, HF Richard: Postpartales Dysgalaktiesyndrom der Sau - eine Übersicht mit besonderer Berücksichtigung der Pathogenese. Tierärztl. Prax. 2009; 37(G): 305-18

M Rolle/ A Mayr Medizinische Mikrobiologie, Infektions- und Seuchenlehre Verlag Enke, 8. Aufl. überarbeitet 2006

J A Rooke and I M Bland: The acquisition of passive immunity in the new-born piglet. Livest Prod Sci 2002; 78: 13-23 (25) 
J A Rooke, C Carranca, I M Bland, A G Sinclair, M Ewen, V C Bland, S A Edwards: Relationships between passive absorption of immunoglobulin $G$ by the piglet and plasma concentrations of immunoglobulin G at weaning. Livest. Prod. Sci. 2003; 81: 223-234 (24)

H Salmon, M Berri, V Gerdts, F Meurens: Humoral and cellular factors of maternal immunity in swine. Dev. Comp. Immunol. 2009; 33: 384-393

D E Scheel, H B Graves and G W Sherritt: Nursing Order, Social Dominance and Growth in Swine. J. Anim. Sci. 1977, 45:219-229

K Schumacher und M Kessler: Quantitative Bestimmung von Serumproteinen durch radiale Immunodiffusion. Z. klin. Chem. klin. Biochem. 1967; 6: 3

J. Sterzl, J. Rejnek and J. Travnicek: Impermeability of pig placenta for antibodies. Folia Microbiologica 1966, Vol 11, Nr. 1: 7-10

B Straw, J J Zimmerman, S D’Allaire, D J Taylor: Diseases of Swine $9^{\text {th }}$ Edition 2006 Blackwell Publishing UK

L S Svendsen, B R Weström, J Svendsen, A C Olsson, B W Karlsson: Intestinal macromolecular transmission in inderprivileged and unaffected newborn pigs: implication for survival of underprivileged pigs. Res. Vet. Sci. 1990; 48:184-189 (abstract)

J Svendsen, B R Weström, A C Olsson: Intestinal macromolecular transmission in newborn pigs: implications for management of neonatal pig survival and health. Livest Prod Sci 2005, 97: 183-191 (26)

I R Tizard: Veterinary Immunology. $8^{\text {th }}$ edition 2009. Saunders Elsevier, St. Louis, Missouri

S Tuboly, G Bernath, R Glavits, I Medveczky: Intestinal absorption of colostral lymphoid cells in newborn pigs: Vet. Immunol. Immunopathol. 1988; 20: 75-85 
M Tuchscherer, E Kanitz, W Otten, A Tuchscherer: Effects of prenatal stress on cellular and humoral immune responses in neonatal pigs. Vet Immunol Immunopathol 2002; 86: 195-203

M A Varley, G J Rucklidge, R J Wilkinson, A Maitland: Enzyme-linked immunosorbent assay for the measurement of immunoglobulin G concentrations in porcine plasma and colostrum. Res. Vet. Sci. 1985; 38: 279-281 (28)

M A Varley, R J Wilkinson, A Maitland: Artificial rearing of baby piglets: the effect of colostrum on survival and plasma concentrations of IgG. Brit. Vet. J. 1987; 143: 369 (29)

E A Wagstrom, K J Yoon, J J Zimmerman: Immune components in porcine mammary secretions. Vir. Immunol. 2000; 13 (3):383-97

E Werhahn, F Klobasa, J E Butler: Investigation of some factors which influence the absorption of IgG by the neonatal piglet. Vet. Immunol. Immunopathol. 1981; 2 (1): 35-51 (30)

P P Williams: Immunmodulating Effects of Intestinal Absorbed Maternal Colostral Leukocytes by Neonatal Pigs. Can. J. Vet. Res. 1993; 57: 1-8

M R Wilson: Immunologic development of the neonatal pig. J. Anim. Sci. 1974: 38(5) 1018-1021

T Yabiki, M Kashiwazaki, S Namioka: Quantitative Analysis of Three Classes of Immunoglobulins in Serum of Newborn Pigs and Milk of Sows. Am. J. Vet. Res. 1974; 35:12 (31)

ZDS: Schweineproduktion in Deutschland 2010, Herausg. 2011 Zentralverband der Deutschen Schweineproduktion e.V. (ZDS) 


\section{Danksagung}

Ganz besonderer Dank gebührt Kees Scheepens, der den Colostrum Quality Counter massgeblich mit entwickelt hat. Seine Schweinesignale ${ }^{\circledR}$ haben mir neue Blickwinkel eröffnet, seine Ideen und seine Begeisterung waren Grundlagen dieser Arbeit. Darüberhinaus sind mir Kees Scheepens und seine Mitarbeiterin Marrit van Engen während der gesamten Arbeit jederzeit hilfreich zur Seite gestanden und haben mich nach Kräften unterstützt.

Mein herzlichster Dank gilt Herrn Prof. Dr. Dr. med. vet. M. Erhard für seine Geduld, sein immer offenes Ohr, seine Ratschläge und nicht zuletzt für die bereitwillige Übernahme dieser externen Arbeit an der Tierärztlichen Fakultät der Ludwig-Maximilians-Universität München. Ebenfalls herzlich gedankt sei Katrin Schuster vom Lehrstuhl Prof. Erhard für Ihre Arbeit im Labor, Ihre Kompetenz, Ihre Sorgfalt und die jederzeit fachkundige Beratung. Dieser Dank gilt ebenso den anderen MitarbeiterInnen im Labor des Lehrstuhls, die bei der Auswertung meiner Proben mitgearbeitet haben.

Bei den Kolleginnen Anke Zankl und Julia Nagel bedanke ich mich herzlich für die Unterstützung im Stall und für jede Menge gute Laune.

Auch bei Wim Schielen und den MitarbeiterInnen der Fa. Prionics möchte ich mich sehr für die Auswertung der Proben und die fachkompetente Beratung bedanken.

Vielen Dank an Rudi Götz, Kurt Engl und Adelheid Keller für die Unterstützung bei der Auswahl und Vermittlung der Betriebe. Den Eigentümern der Betriebe, die mir die Probennahmen in ihren Abferkelställen ermöglicht haben, danke ich ebenfalls herzlich.

Herrn Christoph Molnar vom Institut für Statistik der LMU München danke ich für seine Arbeit und seine immer prompten und geduldigen Antworten und Erklärungen. 


\section{Declaration on oaht / Eidesstattliche Versicherung}

I hereby declare, on oath, that I have written the present dissertation by my own and have not used other than the acknowledged resources and aids.

Hiermit erkläre ich an Eides statt, dass ich die vorliegende Dissertationsschrift selbst verfasst und keine anderen als die angegebenen Quellen und Hilfsmittel benutzt habe.

München, den 26.3.2012

Astrid Pausenberger 